\title{
Platelet factor 4 upregulates matrix metalloproteinase-1 production in gingival fibroblasts
}

\author{
by \\ Mohammad Javaid \\ B.D.S., University of Health Sciences, 2009 \\ M.Sc., McGill University, 2013

\begin{abstract}
A THESIS SUBMITTED IN PARTIAL FULFILLMENT OF
THE REQUIREMENTS FOR THE DEGREE OF
\end{abstract} \\ MASTER OF SCIENCE \\ in \\ THE FACULTY OF GRADUATE AND POSTDOCTORAL STUDIES \\ (Craniofacial Science)
}

THE UNIVERSITY OF BRITISH COLUMBIA

(Vancouver)

December 2016

(C) Mohammad Javaid, 2016 


\section{Abstract}

Background and Objective: Periodontitis is a highly prevalent chronic inflammatory disease that causes tooth loss, morbidity and confers an increased risk for systemic disease. Tissue destruction during periodontitis is due in large part to collagen-degrading matrix metalloproteinases (MMPs) released by resident cells of the periodontium in response to proinflammatory cytokines. Platelets are immune-competent blood cells with a newly recognized role in chronic inflammation, however their role in the pathogenesis of periodontitis is undefined. Consequently, the objective of this study was to assess the effect of platelet factor 4 (PF4), a major platelet-derived cytokine, on MMP-1 (collagenase) expression in human gingival fibroblasts (HGFs).

Methods: HGFs were cultured in the presence or absence of recombinant PF4. Pro-MMP-1 secretion was quantified by enzyme-linked immunosorbent assay (ELISA) analysis of the cell culture supernatants. MMP-1 transcription was quantified by real-time polymerase chain reaction (qPCR). Regulation of MMP-1 production by the p44/42 MAP kinase (MAPK) signaling pathway was examined in the presence or absence of PF4.

Results: Exposure to PF4 caused a 2-3-fold increase in MMP-1 transcription and secretion from cultured human gingival fibroblasts (HGFs). PF4 treatment also enhanced phosphorylation of p44/42 MAP kinase (MAPK), which has been previously shown to induce MMP-1 expression in fibroblasts. Blockade of p44/42 MAPK signaling with the cell-permeant inhibitors PD98059 and PD184352 abrogated PF4-induced pro-MMP-1 transcription upregulation and release from cultured HGFs.

Conclusion: We conclude that platelet factor 4 upregulates MMP-1 expression in human gingival fibroblasts in a p44/42 MAPK-dependent manner. These findings point to a previously unidentified role for platelets in the pathogenesis of periodontal diseases. 


\section{Preface}

This dissertation is an original intellectual product of the author, Mohammad Javaid. Mohammad Javaid performed the laboratory analysis in conjunction with Calvin Biddle and Jiaru Bi. Chapter 2 of this dissertation is presently under review for publication. 


\section{Table of contents}

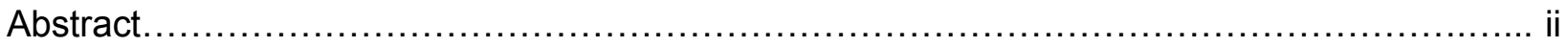

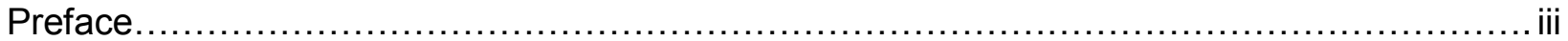

Table of contents

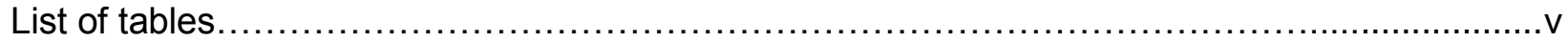

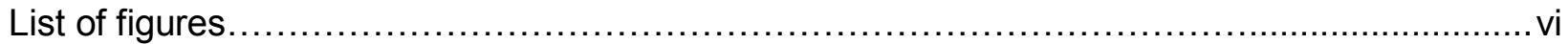

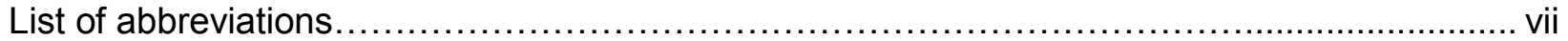

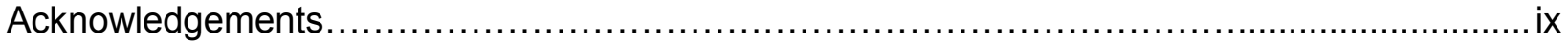

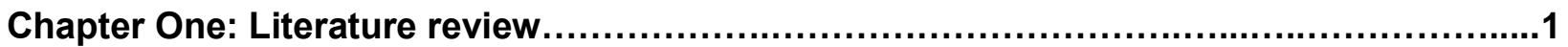

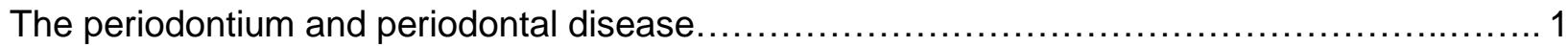

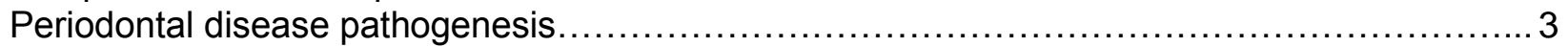

Bacterial infection, cytokine signaling and leukocyte recruitment................................. 3

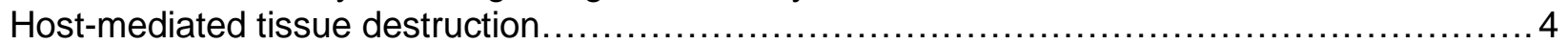

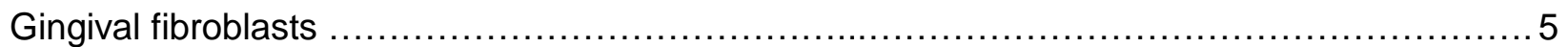

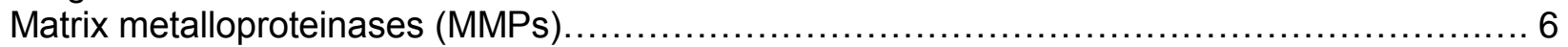

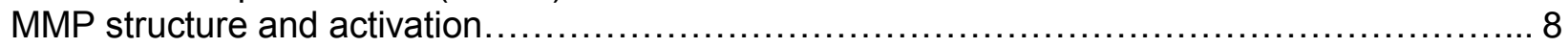

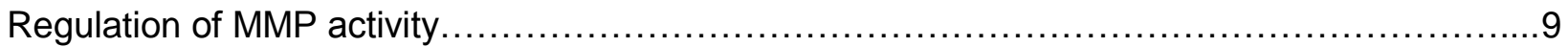

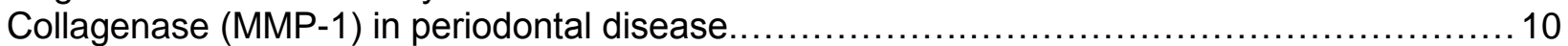

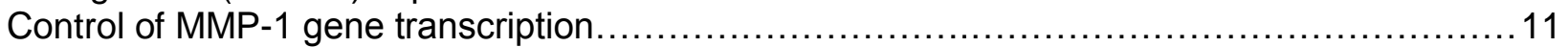

Summary - cytokine signaling and host-mediated tissue degradation.........................15

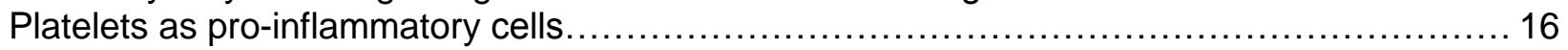

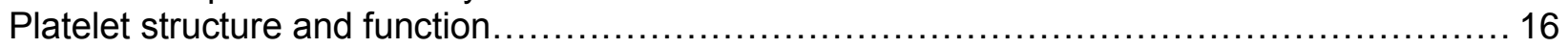

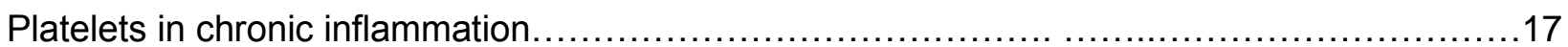

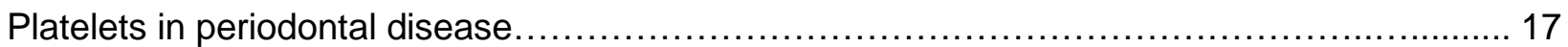

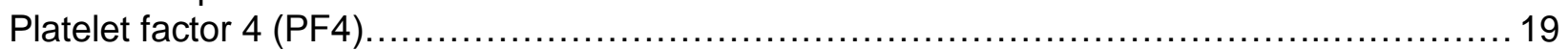

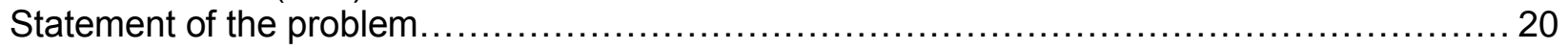

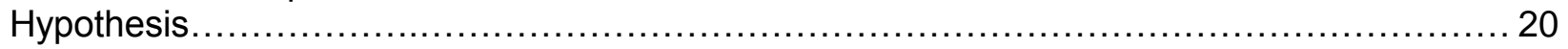

Chapter Two: Chronic periodontitis is associated with platelet factor 4 (PF4) secretion..21

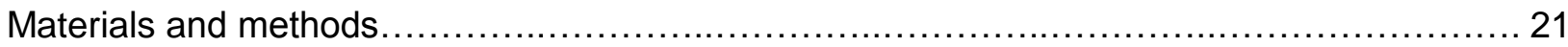

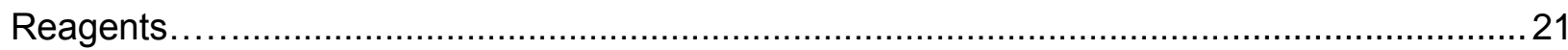

Cell culture, measurement of pro-MMP-1 release, MAPK inhibition and immunoblotting .........21

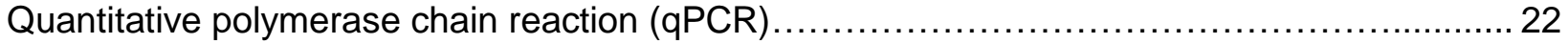

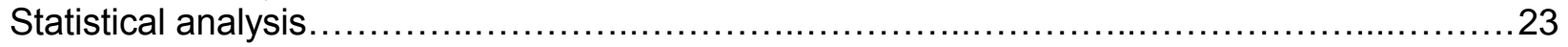

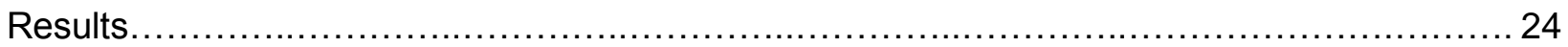

PF4 amplifies the release of MMP-1 from gingival fibroblasts .................................. 24

PF4 increases MMP-1 gene transcription and protein expression.............................. 24

PF4 augments p44/42 MAP kinase signaling in human gingival fibroblasts.......................24

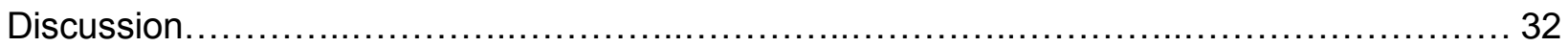

Chapter Three: Conclusions and future directions............................................... 34

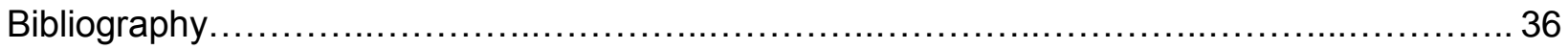




\section{List of tables}

Table 1: List of selected matrix metalloproteinases (MMPs) relevant to periodontitis............. 7 


\section{List of figures}

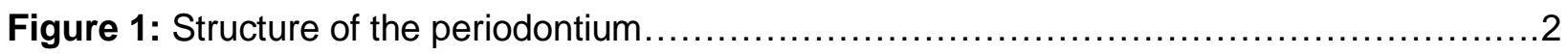

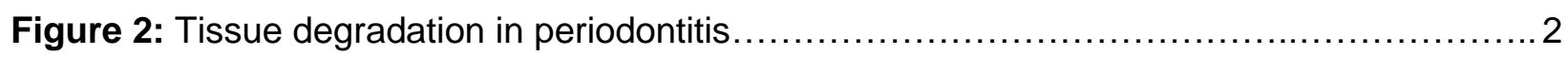

Figure 3: Host response to periodontal infection................................................. 4

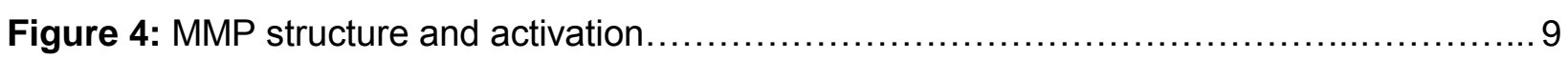

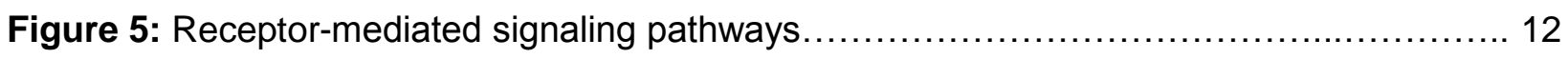

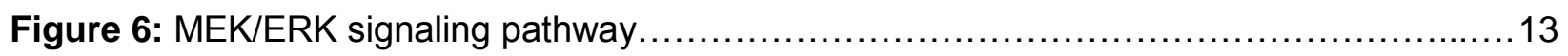

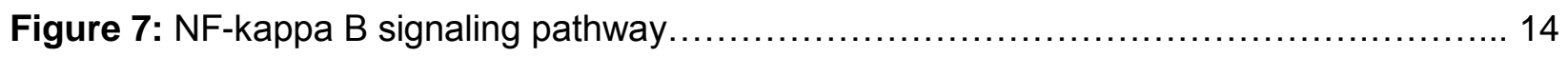

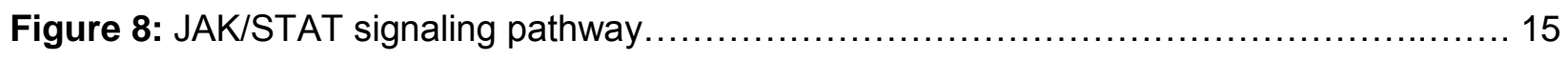

Figure 9: Dose-response effect of PF4 treatment on pro-MMP-1 secretion.......................28

Figure 10: Time-dependent effect of PF4 treatment on pro-MMP-1 secretion.....................29

Figure 11: Platelet factor 4 (PF4) upregulates MMP-1 mRNA expression...................... 30

Figure 12: PF4-induced production of pro-MMP-1 is regulated through p44/42 MAP kinase

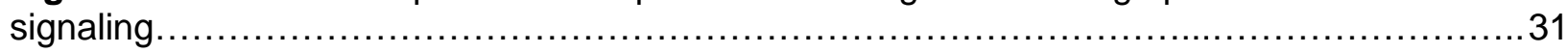




\section{List of abbreviations}

\begin{tabular}{|c|c|}
\hline ALG9 & Alpha-1,2-mannosyltranferase \\
\hline ANOVA & One-way analysis of variance \\
\hline B2M & Beta-2-microglobulin \\
\hline cDNA & Complementary deoxyribonucleic acid \\
\hline CIDP & Chronic inflammatory demyelinating \\
\hline DJG & Dento-gingival junction \\
\hline DNA & Deoxyribonucleic acid \\
\hline ECM & Extracellular matrix \\
\hline ELISA & Enzyme-linked immunosorbent assay \\
\hline ERK & Extracellular signal regulated kinases \\
\hline FGF & Fibroblast growth factor \\
\hline G & Gingiva \\
\hline GAPDH & Glyceraldehyde 3-phosphate dehydrogenase \\
\hline GPCR & G-protein coupled receptor \\
\hline HGF & Human gingival fibroblast \\
\hline IKB & Type of IKK - inhibitor of kappa B kinase \\
\hline IKKs & Inhibitors of kappa B kinases \\
\hline $\mathrm{IL}-1$ & Interleukin-1 \\
\hline IL-1R & Interleukin-1 receptor \\
\hline JAK & Janus kinase \\
\hline JAK/STAT & Janus kinase/signal transducer and activator of transcription \\
\hline MK & Megakaryocyte \\
\hline LPS & Lipopolysaccharide \\
\hline MAP & Mitogen activated protein \\
\hline MAPK & Mitogen activated protein kinase \\
\hline MEK & Mitogen activated protein kinase kinase \\
\hline MEM & Minimum essential medium \\
\hline MIQE & Minimum Information for Publication of Quantitative Real-Time PCR \\
\hline
\end{tabular}


MMP

MMP-1

mRNA

$N F-\kappa B$

NIK

NSVN

PBS

PCR

PF4

PM

PMN

PVDF

qPCR

RNA

rRE

RTK

SDS-PAGE

siRNA

STAT

TAK1

TBS

TIMPs

TLR

TNF- $\alpha$
Matrix metalloproteinase

Matrix metalloproteinase-1

Messenger ribonucleic acid

Nuclear factor kappa light chain enhancer of activated B cells

Nuclear factor kappa light chain enhancer activated B cells induce kinase Non-systemic vasculitic neuropathy

Phosphate buffered saline

Polymerase chain reaction

Platelet factor 4

Plasma membrane

Polymorphonuclear leukocyte (neutrophil)

Polyvinylidene fluoride

Quantitative polymerase chain reaction

Ribonucleic acid

Rough endoplasmic reticulum

Receptor tyrosine kinase

Sodium dodecyl sulfate polyacrylamide gel electrophoresis

Short interfering ribonucleic acid

Signal transducer and activator of transcription

Transforming growth factor-beta activated kinase 1

Tris buffered saline

Tissue inhibitors of matrix metalloproteinases

Toll-like receptor

Tumor necrosis factor alpha 


\section{Acknowledgements}

I offer my deep gratitude to Dr. Hugh Kim, as well as my colleagues in Dr. Kim's and Dr.

Häkkinen's labs and to my fellow students in the Centre for Blood Research and the Graduate Periodontics Department, who inspired me and helped me throughout my work. I owe special thanks to Dr. Lari Häkkinen and to Dr. Ross MacGillivray who were always there to guide me. I would like to acknowledge that I could have not asked for a better supervisor, support team and people - it is their help, mentorship and guidance that has brought this project to its fruition.

Special gratitude is owed to my parents, Javed Khalid and Rabeea Nudrat, my siblings, Juvaria Yasser, Humaira Ahmed and Syed Javed and my uncles Mustahsan Mir and Asad Mir who supported me throughout my studies both financially and morally. 


\section{Chapter One: Literature review}

\section{The periodontium and periodontal disease}

Periodontitis (gum disease) is a chronic inflammatory condition characterized by progressive degradation of the tooth-supporting tissues, collectively called the periodontium (Fig. 1). The periodontium is comprised of the collagenous gingival tissues (gingiva) which cover the toothsupporting alveolar bone; the cementum, a mineralized connective tissue covering the roots of teeth; and the periodontal ligament, a dense connective tissue interspersed between teeth and alveolar bone. The periodontal ligament is chiefly made up of type I and III collagen fibres, cells, blood vessels and nerve fibres (Hanes and Krishna, 2010). The dento-gingival junction is mediated by a junctional epithelium and a connective tissue attachment that connect the gingiva to the tooth. In the healthy periodontium, there is a $2-3 \mathrm{~mm}$ deep space between the gingiva and the tooth, known as the gingival sulcus (Fig. 1).

Periodontal diseases, including gingivitis and chronic periodontitis, affect about half of the adult US population (Eke et al., 2015). In its severe form, periodontitis predisposes patients for tooth loss but also for systemic conditions such as rheumatoid arthritis (Mercado et al., 2000), aspiration pneumonia (Terpenning et al., 2001), cancer (Michaud et al., 2008), atherosclerosis (Tonetti, 2009) and adverse pregnancy outcomes (Eke et al., 2015; Xiong et al., 2006). 


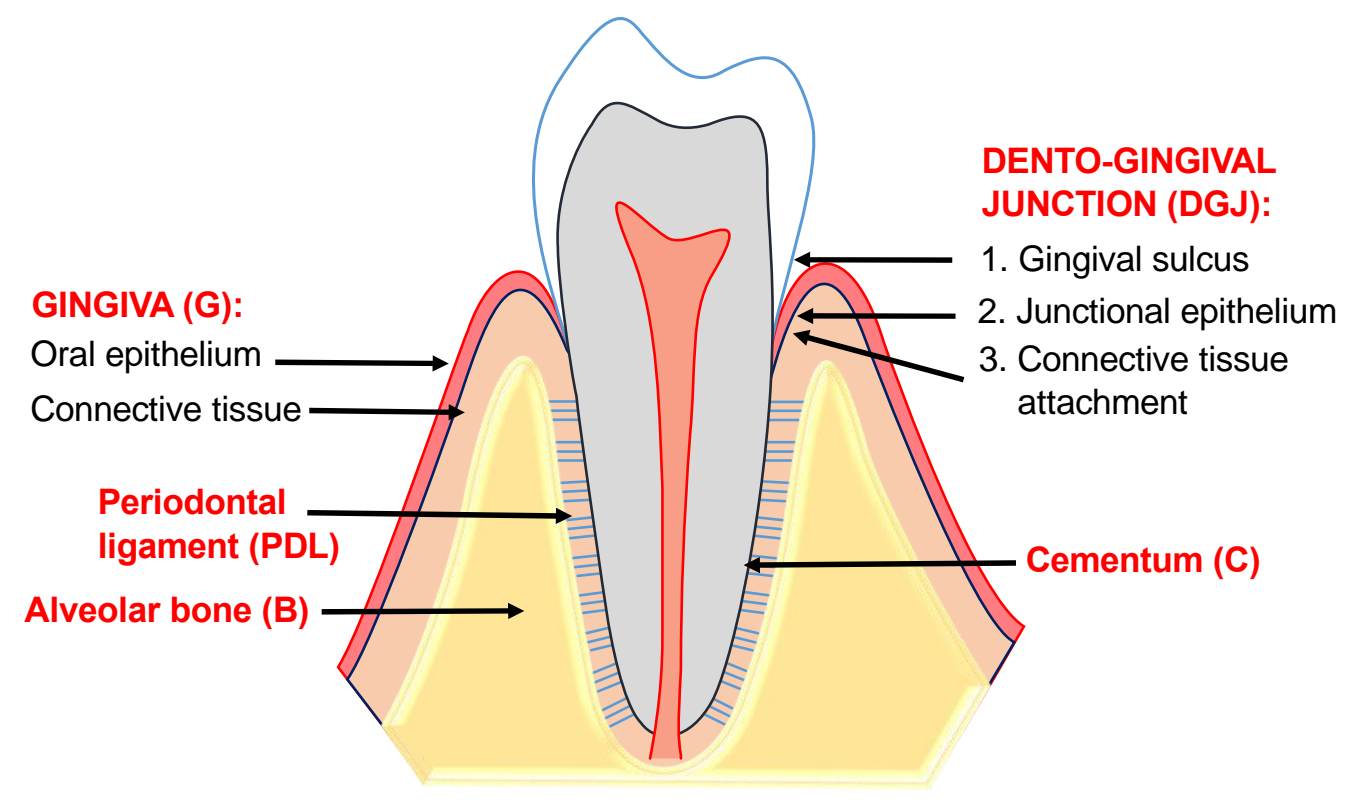

Figure 1. Schematic representation of the periodontium. The gingiva $(\mathrm{G})$ includes epithelium and a connective tissue containing gingival fibroblasts and an extracellular matrix dominated by type I collagen. The dento-gingival junction (DJG) consists of a gingival sulcus, a junctional epithelium and connective tissue attachment.

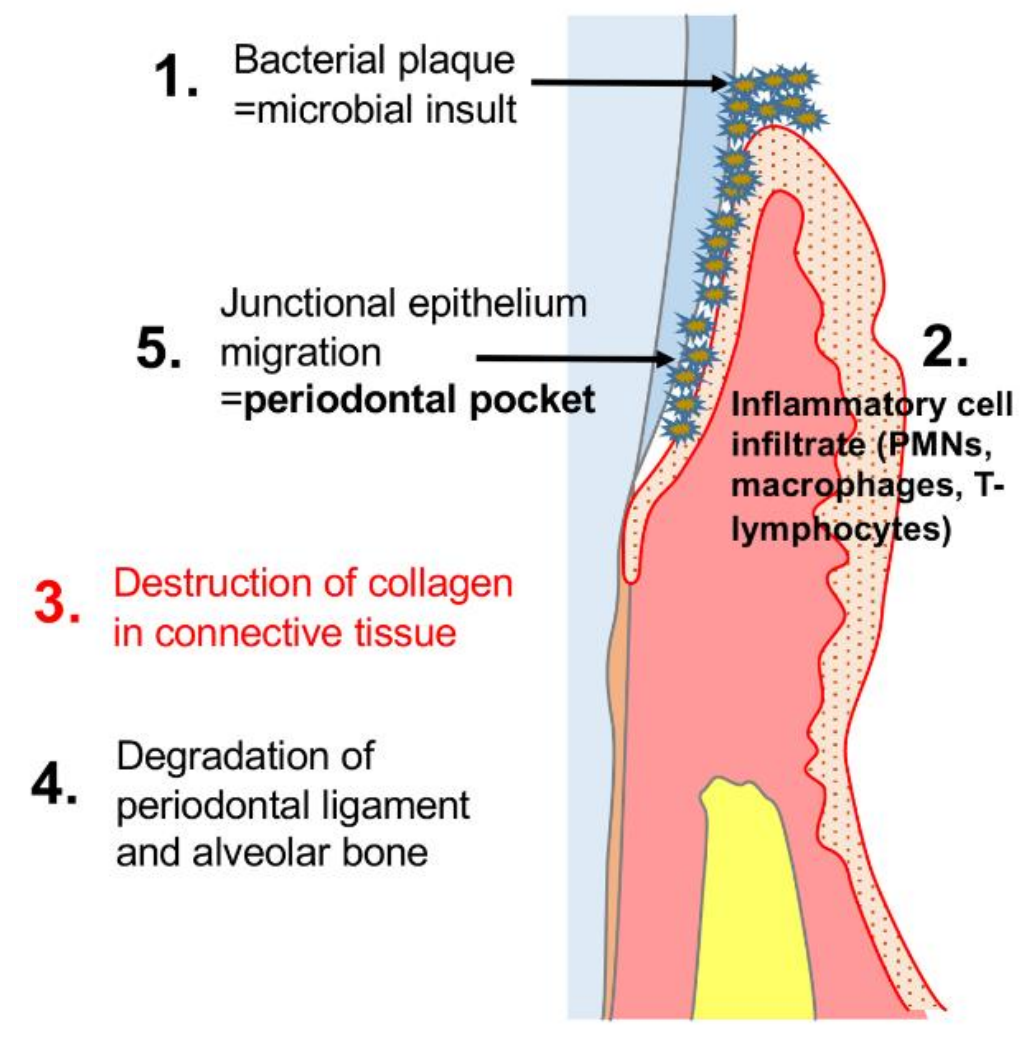


Figure 2. Schematic representation of tissue degradation observed in periodontitis. Colonization of the dento-gingival junction by bacteria-laden dental plaque (1) recruits an inflammatory cell infiltrate (neutrophils, macrophages, T-lymphocytes) (2) that propagates degradation of the collagenous extracellular matrix of the gingival connective tissues (3). The eventual degradation of the alveolar bone and periodontal ligament (4) allows the downward migration of the attachment apparatus of the dento-gingival junction (junctional epithelium and connective tissue attachment), transforming the shallow gingival sulcus into a pathologically deepened "periodontal pocket" (5).

\section{Periodontal disease pathogenesis}

\section{Bacterial infection, cytokine signaling and leukocyte recruitment}

Periodontal inflammation and tissue degradation are initiated by the microbial insult resulting from the accumulation of bacteria-laden dental plaque at the dento-gingival junction (Fig. 2). However, it is an ensuing prolonged or excessive inflammatory response that ultimately results in tissue degradation (Eke et al., 2015; Ramseier et al., 2009). The local proliferation of anaerobic, gram-negative bacteria in the gingival sulcus activates toll-like receptors (TLRs) on host cells that recognize lipopolysaccharide (LPS), the antigenic component of periodontal pathogens (Darveau et al., 2004). TLRs are expressed on multiple cell types in the periodontium, including epithelial cells (Baker et al., 2003; Smith et al., 2003), gingival fibroblasts (Ara et al., 2009; Uehara and Takada, 2007; Wang and Ohura, 2002), neutrophils (Hayashi et al., 2003; Sabroe et al., 2003) and macrophages (Meier et al., 2003; West et al., 2011). In response to ligation of TLRs by bacterial LPS, host cells produce and secrete soluble pro-inflammatory molecules known as cytokines (Kawai and Akira, 2007). Among their multiple functions, cytokines serve to recruit neutrophils (PMNs) en masse to the gingival sulcus (Gursoy et al., 2008; Huang et al., 1998). The neutrophils' phagocytic activity reduces the bacterial burden but their degranulation also release tissue-degrading enzymes (Orozco et al., 2007) including matrix metalloproteinases (MMPs) (Rossa et al., 2007). (Fig. 3). 


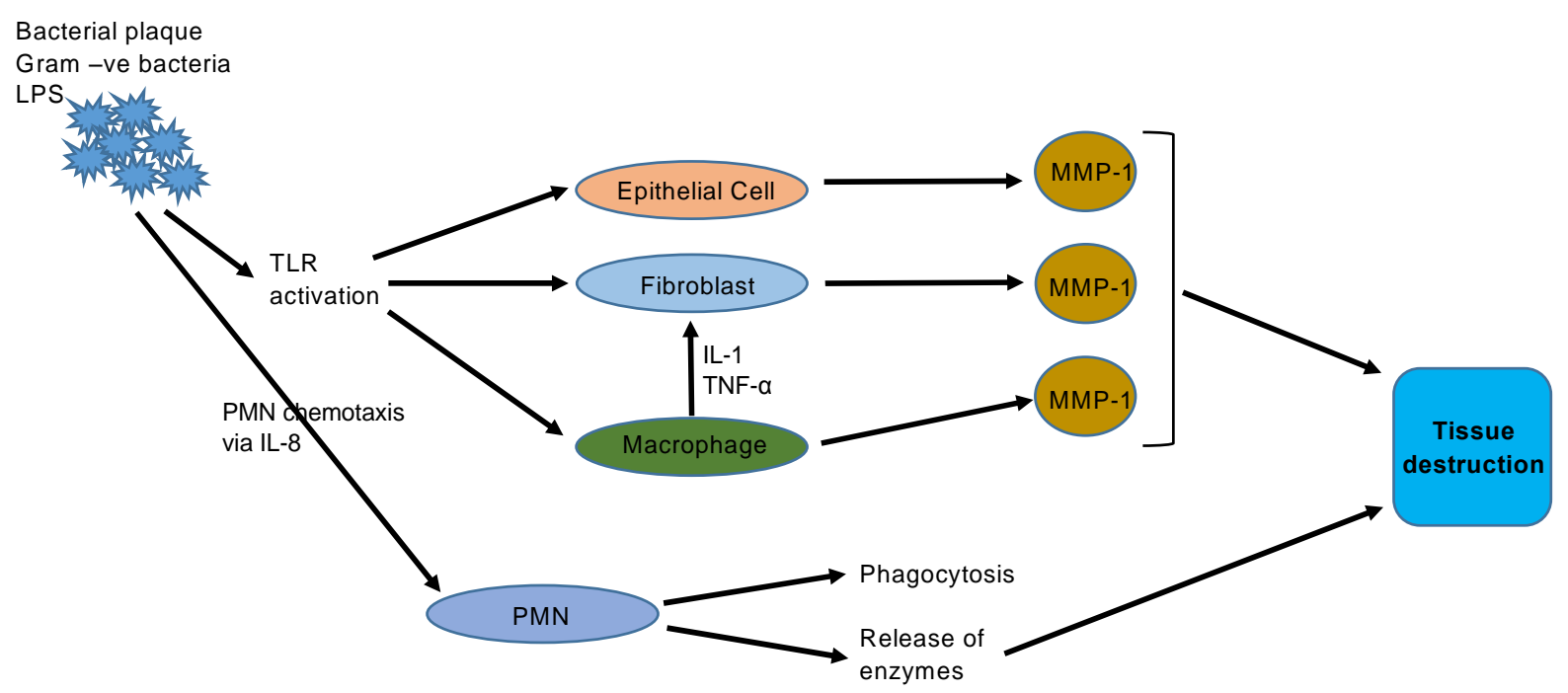

Figure 3. Diagram illustrating selected elements of the host response to periodontal infection. Following the microbial challenge from the bacterial (dental) plaque, neutrophils (PMNs) and monocytes/macrophages are recruited to the dento-gingival junction. PMNs respond to the bacterial challenge by phagocytosis but their degranulation also releases tissue-destructive enzymes including MMPs. Lipopolysaccharide (LPS) from gram-negative periodontal pathogens also activates toll-like receptors (TLRs) on host cells. Pro-inflammatory cytokine signaling (e.g. IL-1, TNF- $\alpha$ ) promotes the release of MMP-1 (collagenase) from resident epithelial cells and gingival fibroblasts in the periodontium, thus contributing to tissue destruction.

\section{Host-mediated tissue degradation}

In addition to recruiting inflammatory leukocytes (PMNs and monocytes) to the periodontium, cytokine signaling also stimulates the production and release of MMPs by resident cells in the periodontium, including gingival epithelial cells and gingival fibroblasts (Fig. 3). The upregulated transcription and release of MMPs from gingival fibroblasts during periodontal disease is welldocumented (DeCarlo et al., 1998; Domeij et al., 2002). For example, macrophages recruited to the periodontal lesion release the cytokines interleukin-1 (IL-1) and tumor necrosis factor alpha (TNF- $\alpha$ ) which in turn promote MMP release by gingival fibroblasts (Kida et al., 2005; Vincenti and Brinckerhoff, 2002). These data provide a partial explanation for the extensive (>70\%) 
collagen degradation that is observed after only 5-7 days of plaque accumulation (Page and Schroeder, 1976).

\section{Gingival fibroblasts}

The gingival fibroblast is the major cellular constituent of the gingival connective tissues. They are responsible for the production and maintenance of the collagenous extracellular matrix (ECM), which provides physical and biochemical support to cells (Tipton and Dabbous, 1995), and ground substance, an amorphous gel-like substance comprised of water, proteoglycans, glycoproteins and glycosaminoglycans (Mariani et al., 1996). Resting fibroblasts have an elongated shape with flattened nucleus. Fibroblasts are endowed with abundant rough endoplasmic reticulum, mitochondria and secretary granules and synthesize and secrete numerous extracellular molecules (Chandra et al., 2004; Nanci, 2008). Most notably, fibroblasts are responsible for the production of type I collagen (Jeng et al., 1996) which is the principal component of the gingival extracellular matrix (Kumada and Zhang, 2010).

Collagen is a fibrillar protein that is first synthesized as procollagen in the gingival fibroblast (Ramachandran, 2013). Amino acids are sequentially assembled into polypeptide chains on ribosomes associated with the rough endoplasmic reticulum (rER) (Lodish et al., 2000; Nanci, 2008). Once formed, these chains are translocated into the lumen of the rER where posttranslational modifications take place, namely, hydroxylation and glycosylation (Kaku and Yamauchi, 2014). First, the lysine and proline residues in the polypeptide chain are hydroxylated, allowing inter chain hydrogen bonding which gives stability to the overall structure and setting the stage for the eventual triple helix conformation characteristic of collagen molecules. (Berkovitz et al., 2009; Garnero et al., 2006; Ruotsalainen et al., 2006). Next, the hydroxylysine residues are glycosylated by the addition of galactose in the rough endoplasmic reticulum (Berkovitz et al., 2009); Role of glycosylation in collagen synthesis is poorly understood (Jürgensen et al., 2011). it is speculated that glycosylation plays a role in the 
collagen fibril formation (Ruotsalainen et al., 2006; Sricholpech et al., 2011). These nascent molecules, termed pro-collagen, are then transported to the Golgi complex where they are packaged for release outside of the cell (Bonfanti et al., 1998; Glick and Malhotra, 1998; Kucharz, 1992). The formation of typical collagen fibrils from pro-collagen molecules occurs in the extracellular matrix (Hay, 2013). Following the removal of C- and N-termini from procollagen, the shortened collagen molecules then arrange into microfibrils which are further assembled into parallel bundles called fibrils (Hay, 2013). These collagen fibrils are further stabilized by oxidative deamination which occurs at some of the lysine and hydroxylysine residues. The oxidative deamination produces reactive aldehyde residues which then participate in the formation of extensive intra- and inter-molecular cross links in the mature collagen structure (Berkovitz et al., 2009; Nanci, 2008; Yamauchi and Sricholpech, 2012).

\section{Matrix metalloproteinases (MMPs)}

Gingival fibroblasts also produce extracellular matrix-degrading enzymes matrixmetalloproteinases (MMPs). Physiologic tissue remodeling requires an ongoing balance between collagen synthesis and degradation, however, excessive MMP production exacerbates extracellular matrix destruction in pathological conditions such as periodontal disease (Guan et al., 2009; Hernández et al., 2007; Kumar et al., 2006), malignancy (Hurst et al., 2007; Salmela et al., 2001), tuberculosis (Elkington et al., 2011), chronic inflammatory demyelinating polyneuropathy (CIDP) and non-systemic vasculitic neuropathy (NSVN) (Leppert et al., 1999), ischemia-reperfusion injury (Chen et al., 2003), dilated cardiomyopathy (Spinale et al., 2000), viral meningitis (Kolb et al., 1998), chronic constriction neuropathy (Shubayev and Myers, 2000) and multiple sclerosis (Leppert et al., 1998). In each of these conditions, deregulation of MMP production and/or release of MMPs leads to tissue destruction and loss of function. MMPs are a large family of zinc-containing, (Isaksen and Fagerhol, 2001) calcium-dependent endopeptidases with catalytic properties (Visse and Nagase, 2003). MMPs are responsible for 
degradation of extracellular matrix and tissue remodelling (Mott and Werb, 2004; Visse and

Nagase, 2003). Over 20 MMPs have been identified to date (Shimada et al., 2009), several of which are germane to the tissue degradation observed in periodontitis. (Table 1).

Table 1. List of selected MMPs relevant to periodontal tissue degradation.

\begin{tabular}{|c|c|c|c|c|}
\hline Name(s) & $\begin{array}{l}\text { Cellular } \\
\text { source }\end{array}$ & $\begin{array}{l}\text { Target } \\
\text { tissues/molecules }\end{array}$ & $\begin{array}{l}\text { Relevance to } \\
\text { periodontal disease }\end{array}$ & Reference \\
\hline $\begin{array}{l}\text { MMP-1 } \\
\text { (collagenase) }\end{array}$ & $\begin{array}{l}\text { Keratinocytes, } \\
\text { Monocytes, } \\
\text { PMNs, } \\
\text { Fibroblasts }\end{array}$ & $\begin{array}{l}\text { Collagen type I and } \\
\text { III, ECM }\end{array}$ & $\begin{array}{l}\text { Plays a role in tissue } \\
\text { destruction in } \\
\text { periodontal disease, } \\
\text { MMP-1 levels in GCF } \\
\text { decrease and ratio of } \\
\text { MMP-1 to TIMP-1 } \\
\text { becomes close to } \\
\text { controls after } \\
\text { periodontal therapy }\end{array}$ & $\begin{array}{l}\text { (Achong et al., } \\
\text { 2003; Astolfi et } \\
\text { al., 2006; De } \\
\text { Souza et al., } \\
\text { 2003; Ingman et } \\
\text { al., 1994; Li et } \\
\text { al., 2012; Tüter } \\
\text { et al., 2002)s }\end{array}$ \\
\hline $\begin{array}{l}\text { MMP-2 } \\
\text { (gelatinase) }\end{array}$ & $\begin{array}{l}\text { Fibroblasts, } \\
\text { Keratinocytes, }\end{array}$ & $\begin{array}{l}\text { Collagen type I, IV, } \\
\text { V, VII, XI, } \\
\text { denatured collagen } \\
\text { (gelatin), ECM }\end{array}$ & $\begin{array}{l}\text { Suspected to play a role } \\
\text { in ECM degradation in } \\
\text { Periodontitis, involved } \\
\text { in tissue destruction } \\
\text { associated with human } \\
\text { chronic periodontitis }\end{array}$ & $\begin{array}{l}\text { (Achong et al., } \\
\text { 2003; Korostoff } \\
\text { et al., 2000; } \\
\text { Makela et al., } \\
\text { 1994) }\end{array}$ \\
\hline $\begin{array}{l}\text { MMP-3 } \\
\text { (stromelysin-1) }\end{array}$ & $\begin{array}{l}\text { Keratinocytes, } \\
\text { Chondrocytes, } \\
\text { Synovial cells, } \\
\text { Preadipocytes }\end{array}$ & $\begin{array}{l}\text { Fibronectin, } \\
\text { Laminin, Collagen } \\
\text { II, III, IV, V, VI, } \\
\text { IX, X, Elastin, } \\
\text { Laminin }\end{array}$ & $\begin{array}{l}\text { Can activate other } \\
\text { MMPs including MMP- } \\
1 \text { and MMP-9, } \\
\text { associated with } \\
\text { periodontal disease } \\
\text { progression }\end{array}$ & $\begin{array}{l}\text { (Astolfi et al., } \\
\text { 2006; Birkedal- } \\
\text { Hansen, 1993; } \\
\text { Chen et al., } \\
\text { 2014; Gao and } \\
\text { Bing, 2011; } \\
\text { Letra et al., } \\
\text { 2012; } \\
\text { McCawley et al., } \\
\text { 2008; Reddy et } \\
\text { al., 2012; } \\
\text { Sternlicht et al., } \\
\text { 1999) }\end{array}$ \\
\hline $\begin{array}{l}\text { MMP-8 } \\
\text { (neutrophil } \\
\text { collagenase) }\end{array}$ & $\begin{array}{l}\text { Keratinocytes, } \\
\text { PMNs, } \\
\text { Fibroblasts, } \\
\text { Endothelial } \\
\text { cells }\end{array}$ & $\begin{array}{l}\text { Type I, II and III } \\
\text { collagen }\end{array}$ & $\begin{array}{l}\text { Contributes to } \\
\text { collagenase activity in } \\
\text { GCF, subantimicrobial } \\
\text { doxycycline (SDD) } \\
\text { reduces GCF } \\
\text { collagenase activity and } \\
\text { MMP-8 levels and }\end{array}$ & $\begin{array}{l}\text { (Emingil et al., } \\
\text { 2004; Golub et } \\
\text { al., 1998; Kiili et } \\
\text { al., 2002; Wen et } \\
\text { al., 2015) }\end{array}$ \\
\hline
\end{tabular}




\begin{tabular}{|c|c|c|c|c|}
\hline & & & $\begin{array}{l}\text { improves clinical } \\
\text { parameters }\end{array}$ & \\
\hline Name(s) & $\begin{array}{l}\text { Cellular } \\
\text { source }\end{array}$ & $\begin{array}{l}\text { Target } \\
\text { tissues/molecules }\end{array}$ & $\begin{array}{l}\text { Relevance to } \\
\text { periodontal disease }\end{array}$ & Reference \\
\hline $\begin{array}{l}\text { MMP-9 } \\
\text { (gelatinase B) }\end{array}$ & $\begin{array}{l}\text { Keratinocytes, } \\
\text { PMNs }\end{array}$ & $\begin{array}{l}\text { Collagen type I, IV } \\
\text { and denatured } \\
\text { collagen (gelatin) }\end{array}$ & $\begin{array}{l}\text { Diseased periodontal } \\
\text { tissues have higher } \\
\text { levels of MMP-9, } \\
\text { suspected to participate } \\
\text { in tissue destruction } \\
\text { observed in periodontal } \\
\text { disease, levels decrease } \\
\text { after periodontal } \\
\text { therapy }\end{array}$ & $\begin{array}{l}\text { (Achong et al., } \\
\text { 2003; Makela et } \\
\text { al., 1994; } \\
\text { Marcaccini et } \\
\text { al., 2010; Smith } \\
\text { et al., 2004) }\end{array}$ \\
\hline $\begin{array}{l}\text { MMP-12 } \\
\text { (elastase) }\end{array}$ & Macrophage & $\begin{array}{l}\text { Collagen type I, IV, } \\
\text { Gelatin, Elastin, } \\
\text { Fibronectin, } \\
\text { Proteoglycan, } \\
\text { Laminin }\end{array}$ & $\begin{array}{l}\text { Elevated GCF levels in } \\
\text { sites with aggressive } \\
\text { periodontal disease, } \\
\text { Correlated with deeper } \\
\text { PD, Levels are reduced } \\
\text { after periodontal } \\
\text { therapy, may play a role } \\
\text { in age associated } \\
\text { periodontal tissue } \\
\text { changes (tissue } \\
\text { destruction and } \\
\text { attachment loss) }\end{array}$ & $\begin{array}{l}\text { (Desarda and } \\
\text { Gaikwad, 2013; } \\
\text { Gonçalves et al., } \\
\text { 2013; Kim et al., } \\
\text { 2016) }\end{array}$ \\
\hline $\begin{array}{l}\text { MMP-13 } \\
\text { (collagenase 3) }\end{array}$ & $\begin{array}{l}\text { Keratinocytes, } \\
\text { Fibroblasts }\end{array}$ & $\begin{array}{l}\text { Collagen, Gelatin, } \\
\text { Entactin, Pro-TNF } \\
\text { alpha }\end{array}$ & $\begin{array}{l}\text { Elevated levels in GCF } \\
\text { of patients with } \\
\text { progressive periodontal } \\
\text { disease, suspected to } \\
\text { play role in tissue } \\
\text { destruction in } \\
\text { periodontal disease, } \\
\text { breakdown of } \\
\text { connective tissue } \\
\text { collagen }\end{array}$ & $\begin{array}{l}\text { (Hernandez et } \\
\text { al., 2006; Uitto } \\
\text { et al., 1998; } \\
\text { Vandenbroucke } \\
\text { et al., 2013) }\end{array}$ \\
\hline
\end{tabular}

\section{MMP structure and activation}

MMPs are multi-domain, calcium-dependent proteins that contain a zinc ion surrounded by three histidine residues at the catalytic or active site (Hu et al., 2007). The catalytic domain mediates the proteolysis of specific substrates such as collagen (Glasheen et al., 2009; Ra and 
Parks, 2007). In addition to the catalytic domain, MMPs contain a pro-domain, a hinge region and a hemopexin domain (Nagase et al., 2006) (Fig. 4A). The hemopexin domain confers MMP-to-substrate specificity by facilitating MMP binding only with specific molecules such as heparin (Wallon and Overall, 1997), fibronectin (Wallon and Overall, 1997) and tissue inhibitors of MMPs, abbreviated as TIMPs (Dufour et al., 2008; Roeb et al., 2002; Tallant et al., 2010). There is also a hinge region linking the catalytic and hemopexin domains (Bauvois, 2012; Visse and Nagase, 2003).

Most MMPs are produced as inactive pro-enzymes or zymogens (Ramos-DeSimone et al., 1999). Pro-MMPs are kept in their latent state by strong interactions between the zinc ion of the catalytic site and the pro-domain. MMP activation occurs by proteolysis and removal of the prodomain, thus exposing the catalytic site to the corresponding substrates (Golubkov et al., 2010; Nagase et al., 2006) (Fig. 4B). MMPs can also be cleaved by other MMPs, by serum plasmin or by non-enzymatic molecules such as mercurial compounds, SH-active agents, gold compounds and detergents (Malemud, 2005; Sapna et al., 2014; Visse and Nagase, 2003).

A.

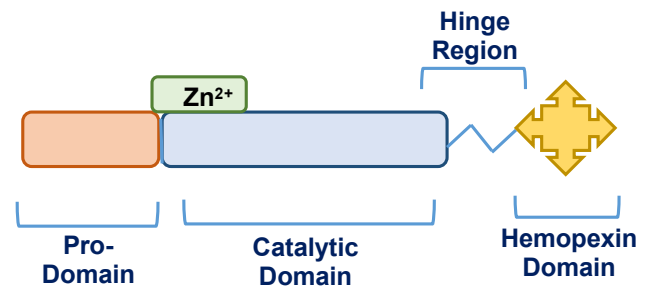

B.

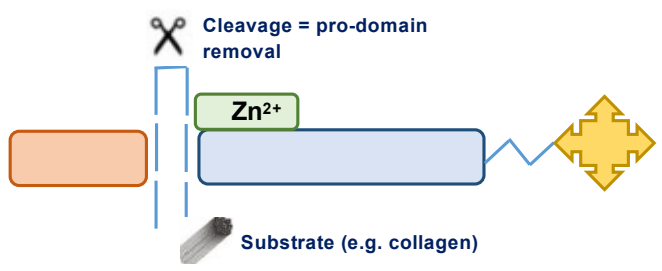

Figure 4. A. Schematic diagram illustrating the general structure of an MMP molecule, including the pro-domain, the catalytic domain, hinge region and hemopexin domain. A zinc ion $\left(\mathrm{Zn}^{2+}\right)$ is present at the catalytic site. B. Schematic illustration of MMP activation. Removal of the pro-domain by proteolytic cleavage exposes the catalytic domain to extracellular matrix substrates such as collagen. 


\section{Regulation of MMP activity}

To ensure homeostasis, proteolysis and tissue remodelling need to be held in balance with protein synthesis. MMP activity can be regulated by natural inhibitors called tissue inhibitors of matrix metalloproteinases (TIMPs) which inhibit MMPs by binding to catalytic (Khokha et al., 2013; Page-McCaw et al., 2007) domains of MMPs (Brew and Nagase, 2010). Endogenous inhibitors of MMPs included alpha 2-macroglobulin, a circulating protease inhibitor (Tortorella et al., 2004; Wang et al., 2014). Synthetic MMP inhibitors have also been developed for therapeutic purposes (Caton et al., 2000; Crout et al., 1996). TIMPs abrogate MMP activity by binding to the catalytic domain and forming complexes with MMPs in their latent or inactive form (Brew and Nagase, 2010; Jezierska and Motyl, 2009; Lijnen, 2001; Murphy, 2011; Sang, 1998; Zucker et al., 1998). The balance between MMPs and TIMPs is critical for maintenance of health of tissues; for example, a net increase of MMPs or a net decrease in TIMPs promotes collagen tissue destruction in periodontal disease (Cifcibasi et al., 2015; Garlet et al., 2004; Sapna et al., 2014).

\section{Collagenase (MMP-1) in periodontal disease}

MMP-1, or collagenase, is perhaps the most notorious MMP in the context of periodontal disease pathogenesis (Sorsa et al., 2004) that is upregulated in gingival fibroblasts in response to direct stimulation by LPS (Bozkurt et al., 2016) or by pro-inflammatory cytokines such as IL-1 (Bauer et al., 2009; Kaden et al., 2003). Accordingly, increased levels of MMP-1 were observed in gingival tissue samples obtained from periodontitis patients, compared to healthy controls (Beklen et al., 2007). Moreover, fluids harvested from the gingival sulcus (gingival crevicular fluid) contain higher levels of MMP-1 in periodontitis patients compared to healthy controls (Ingman et al., 1996; Ko, 2012; Sorsa et al., 2004). Similarly, gingival tissues from periodontitis patients express more MMP-1 mRNA compared to healthy controls (Kubota et al., 1996). Collectively, these data all point to an increase in local MMP-1 production during periodontal 
inflammation, suggesting its importance as a critical component of periodontal disease pathogenesis. Given that gingival fibroblasts are the predominant cells of the periodontal connective tissue, it is of considerable interest to identify the precise mechanisms by which MMP-1 is expressed in these cells.

\section{Control of MMP-1 gene transcription}

In eukaryotic cells, protein production is regulated by transcription, where genetic information stored in DNA is transcribed into messenger RNA (mRNA), which serves as a template for protein synthesis (Cooper and Ganem, 1997). Transcription takes place in the cell's nucleus and is initiated by RNA polymerase II, an enzyme which binds a specific sequence of nucleic acids in the DNA strand, termed the promoter (Harvey and Ferrier, 2011). Binding of the enzyme RNA polymerase II to the gene's DNA promoter uncoils the DNA strands in the double helix, allowing the formation of a complementary mRNA strand (Harvey and Ferrier, 2011). This newly formed mRNA molecule is edited via splicing to remove noncoding RNA (introns) and then exported to the cytoplasm where it is translated into protein (Harvey and Ferrier, 2011).

Several different signaling pathways can regulate the transcriptional control of MMPs. Intracellular signaling cascades are triggered when an extracellular signalling molecule, or ligand, binds a specific receptor on the cell surface (Fig. 5). Binding of a ligand with a cell surface receptor initiates a chain of biochemical events in the cell that culminates in a downstream physiologic response (Lodish and Zipursky, 2001), such as up- or downregulation of expression of a target gene (Krauss, 2006). There are several well-characterized signaling pathways implicated in MMP-1 expression in gingival fibroblasts, including the mitogen activated protein kinase (MAPK) pathway; the NF-kappa B (NF-kB) pathway, and the Janus Kinase/Signal Transducer and Activator of Transcription (JAK/STAT) pathway. The multitude of ligand/receptor combinations that activate each of these pathways underscore the complexity of MMP-1 transcriptional control. 


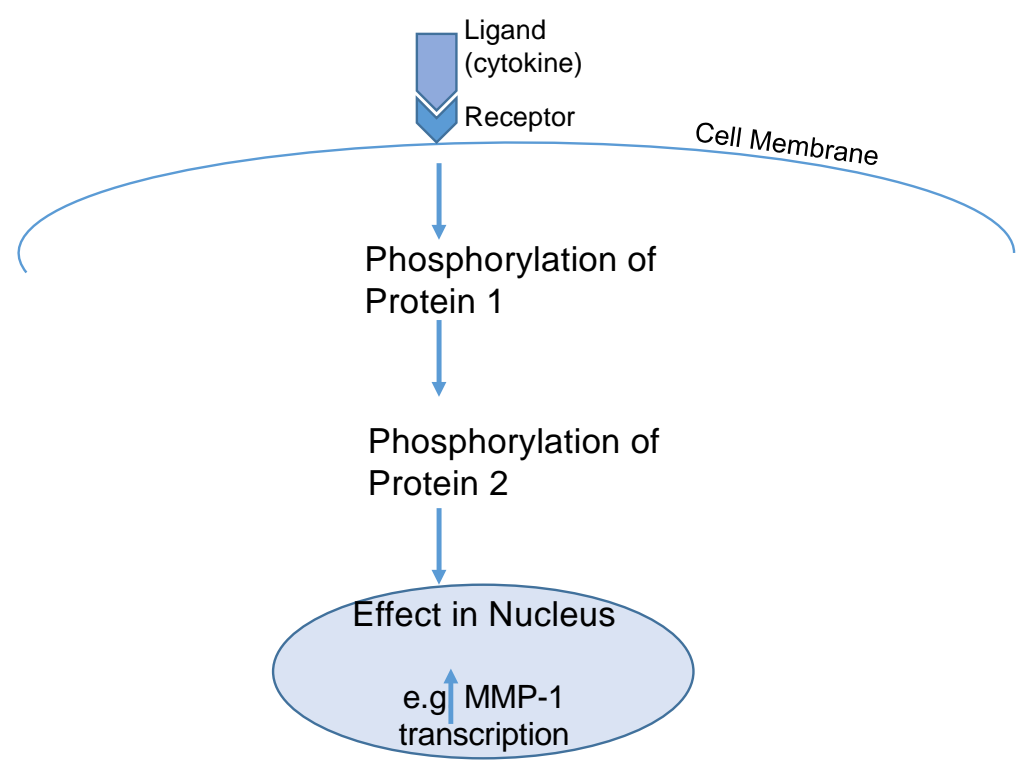

Figure 5. Diagram illustrating the general mechanism of receptor-driven cell signaling pathways. The binding of a ligand (e.g. a soluble cytokine) to its matching cell surface receptor triggers changes in intracellular proteins. Sequential phosphorylation of intracellular proteins by protein kinases is a common mechanism by which extracellular signals are transduced and delivered to effect changes in cell behavior, for example, up- or down-regulation of gene transcription and/or protein expression

MAPK pathway: The MAPK pathway comprises of series of protein kinases that play a central role in signal transduction in eukaryotic cells (Cooper and Ganem, 1997). Protein kinases are enzymes that catalyze the transfer of phosphate group to specific amino acids in a process known as phosphorylation (Johnson and Lapadat, 2002), which can serve to activate or abrogate the physiologic activity of the phosphorylated protein. In the MAPK pathway, extracellular signaling molecules, including pro-inflammatory cytokines, trigger the sequential phosphorylation and activation of the proteins Ras, B-Raf, MEK1/2, and ERK1/2 (also known as p44/42) (Roux and Blenis, 2004). ERK then enters the fibroblast's nucleus 


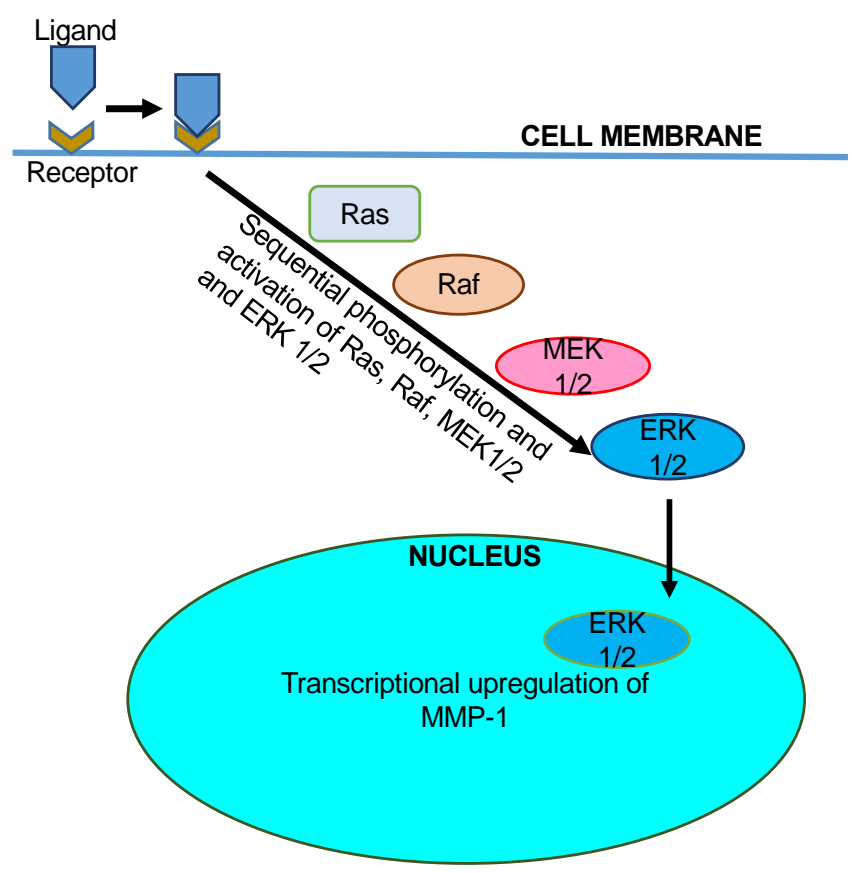

Figure 6. Schematic diagram illustrating MAP kinase (MEK/ERK) signaling. Binding of a soluble ligand with its corresponding receptor triggers the sequential phosphorylation and activation of the proteins Ras, Raf, MEK and ERK. ERK translocates into the cell's nucleus where it binds and activates the MMP-1 promoter, thus upregulating its expression.

where it activates the MMP-1 promoter, thus stimulating transcription of the MMP-1 gene (Nagase and Woessner, 1999) (Fig. 6). Specifically, ERK phosphorylates and activates cJun which then dimerizes with c-Fos which results in an increase in the rate of MMP-1 gene transcription (Vincenti and Brinckerhoff, 2002).

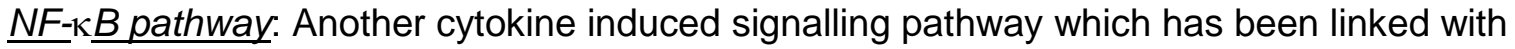
MMP expression is nuclear factor-KB (NF- $\kappa B$ ) pathway (Vincenti, 2001) (Fig. 7). In one example, binding of interleukin (IL-1) with the IL-1 receptor (IL-1R) activates transforming growth factor-beta activated kinase 1 (TAK1) which then activates NF- $\kappa B$-inducing kinase (NIK). NIK then phosphorylates and activates inhibitors of Kappa B kinases (IKKs) which phosphorylates a second protein, called IKB. Phospho-IKB is then conjugated to another protein (ubiquitin) making it a target for proteasomes, which degrade the ubiquinated IKB 
(Peters et al., 1994). In resting cells, IKB binds and sequesters dimers of p50/p65 protein in the cytoplasm. Degradation of the phospho-IKB-ubiqutin frees the effector p50/p65 protein which translocates to the nucleus where it activates MMP-1 transcription (Chakraborti et al., 2003; Vincenti and Brinckerhoff, 2002).

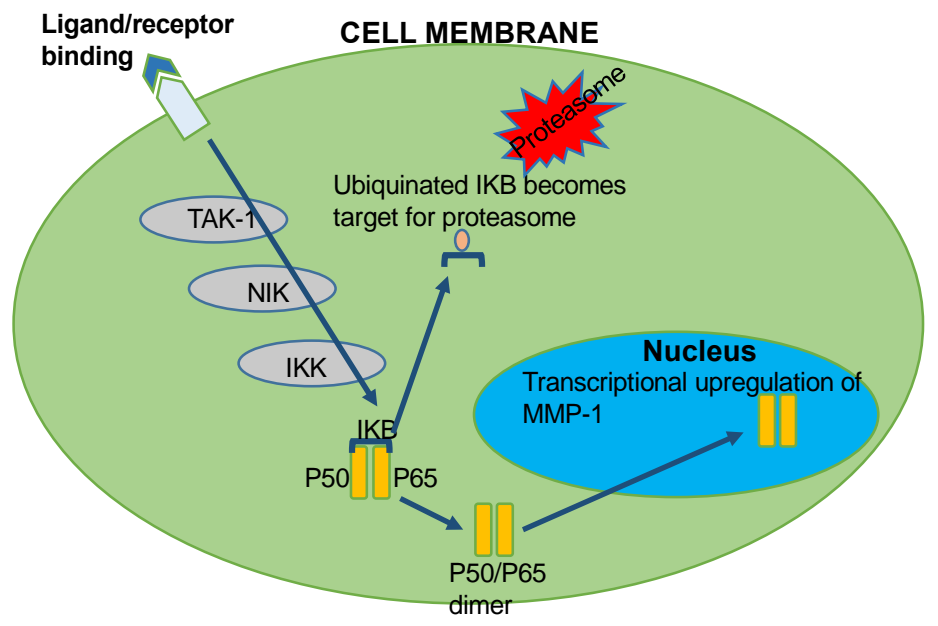

Figure 7. Schematic illustration of the NF-kappa B signaling pathway. Ligand/cell surface receptor binding triggers the sequential phosphorylation and activation of the proteins TAK-1, NIK, IKK and IKB, which is bound to the P50/P65 protein dimer. Proteasomal degradation of IKB frees the P50/P65 dimer which then enters the nucleus to drive transcriptional upregulation of MMP-1.

JAK-STAT pathway: The JAK-STAT pathway may also regulate MMP-1 expression (Fig. 8).

This pathway can be activated by growth hormones (Brooks et al., 2014) or cytokines including interferon-gamma (Darnell Jr et al., 1994; Lim and Kim, 2011; Liu et al., 2008). Binding of the ligand to its corresponding receptor results in monomer clustering (multimerization) of the receptor subunits (Rawlings et al., 2004). Receptor-bound JAK kinases become juxtaposed which recruits latent cytoplasmic transcription factors termed STATs (Lim and Kim, 2011). STATs contain a phospho-tyrosine binding SH2 domain that can be phosphorylated by JAKs. After activation by tyrosine phosphorylation, STATs form homodimers or heterodimers that can translocate to the nucleus where they bind the DNA promoters of target genes such as MMP-1 (Korzus et al., 1997; Rawlings et al., 2004). 


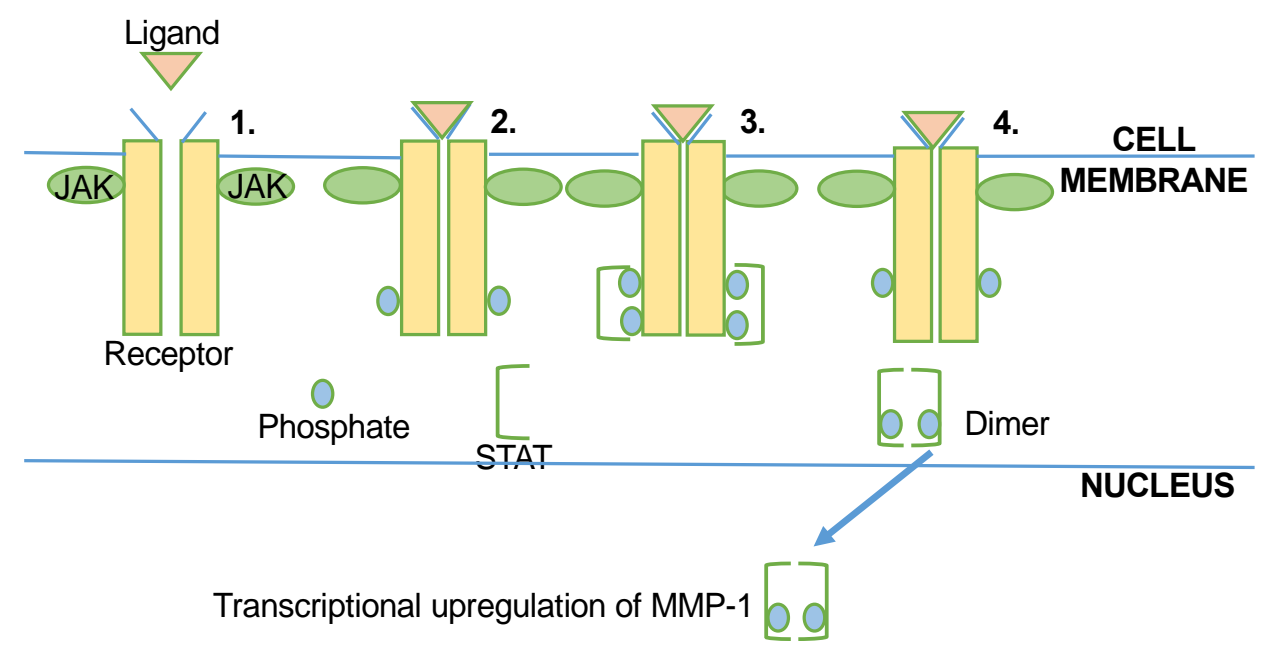

Figure 8. Schematic diagram of JAK-STAT signaling. In this pathway, ligand binding at the cell surface leads to receptor clustering and the recruitment of JAK kinases (1), followed by the the subsequent recruitment and phosphorylation of STATs (2-3). The dimerization of STATs (4) and their subsequent entry into the cell's nucleus promotes the upregulation of MMP-1 gene transcription.

\section{SUMMARY - cytokine signaling and host mediated tissue degradation}

Periodontal disease is initiated by a gram-negative bacterial infection that induces TLR activation and pro-inflammatory cytokine release by leukocytes recruited to the periodontium (e.g. neutrophils, macrophages, T-lymphocytes). Cytokine signaling in the inflamed periodontium is partly responsible for the production and release of tissue-degrading MMPs from gingival fibroblasts residing in the periodontium. However, the precise cytokines and associated signaling pathways that determine MMP release from gingival fibroblasts are still not completely defined. 


\section{Platelets as pro-inflammatory cells}

\section{Platelet structure and function}

Platelets are small $(2-5 \mu \mathrm{m})$, anucleate cells that circulate in large numbers in the human bloodstream (130,000 to 400,000 platelets per microliter of whole blood) (Martin, 2008). Platelets are released as membrane-bound discoid fragments by megakaryocytes of bone marrow and have an average lifespan of 7-10 days (Marcus, 1978). Like other cell types, platelets also contain, lysosomes, mitochondria and an endoplasmic reticulum (Orkin et al., 2008). In addition to lysosomal granules, platelets also contain two specific types of granules, termed the alpha $(\alpha)$ granules and dense granules that contain numerous adhesive proteins and cytokines that are released upon activation of platelets by tissue injury or in response to endogenous or host-derived soluble signals (Battinelli et al., 2011; Chen et al., 2000; Jenne et al., 2013; Klinger and Jelkmann, 2002; Rinder et al., 1993). Platelets also exhibit multiple membrane invaginations contiguous with the open canalicular system, a network of channels that act as conduits for the secretion of the activated platelet's granular content (Escolar and White, 1990; Hartwig, 2002; White and Escolar, 1991; White and Clawson, 1980).

Platelets originate from megakaryocytes (MKs) which reside in bone marrow (PEASE, 1956). The process of platelet formation can be arbitrarily divided into two phases. During the first phase, MKs experience massive nuclear proliferation, cytoplasmic enlargement and increased cytoskeletal protein synthesis. In the second phase, MKs generate platelets by forming multiple extended projections called proplatelets (Nagata et al., 2003; Patel et al., 2005b) which subsequently undergo fission-like shape changes that release discoid platelets (Ebbe et al., 1965; Odell and Jackson, 1968; Odell et al., 1970). Prior to platelet generation, the parent MKs undergo endomitosis, a process which involves DNA replication without cell division (Machlus and Italiano, 2013; Patel et al., 2005a). The exact signals that trigger proplatelet formation in the MK are not fully understood (Machlus and Italiano, 2013). However, it is known that the shafts of 
the proplatelets are lined by microtubules that transport organelles and granules into the nascent platelets (Machlus and Italiano, 2013). A single MK can have 10-20 proplatelets that exhibit multiple branches.

It was previously thought that platelets are noncomplex cells with the sole function of arresting hemorrhage (Harrison and Goodall, 2008). However, activated platelets also release multiple growth factors (Assoian and Sporn, 1986; Heemskerk and Sage, 1994; Möhle et al., 1997), and adhesion molecules stored in their granules (Parise, 1999; Woulfe et al., 2002). It is noteworthy that platelets lack nuclei and thus DNA-to-mRNA transcription does not occur in platelets without the exception of mitochondrial DNA that encodes for some mRNA and ribosomal RNA (Gnatenko et al., 2003; Weyrich and Zimmerman, 2003). Consequently, the bulk of the platelet proteome is pre-formed by the MK and packaged into platelets (Weyrich et al., 2004).

\section{Platelets in chronic inflammation}

Although platelets are well-known for their functions in hemostasis, they also store and release an abundance of pro-inflammatory cytokines (Semple and Freedman, 2010). Multiple lines of evidence now indicate that platelets contribute to chronic inflammation. For example, arthritic disease is milder in thrombocytopenic mice compared to controls (Semple et al., 1996). Similarly, asthmatic inflammation and bronchoconstriction are suppressed by platelet depletion

(Vincent et al., 1993) and platelet function is elevated in asthmatic humans (Idzko et al., 2015). In addition, platelets contribute to gut inflammation observed in ulcerative colitis and Crohn's disease (Danese et al., 2004). Taken together, these data indicate a role for platelets in promoting the pathogenesis of chronic inflammatory diseases.

\section{Platelets in periodontal disease}

Consistent with existing evidence of a pro-inflammatory role for platelets, current indirect evidence supports a role for platelets in periodontal disease. For example, data from several 
animal studies point to a pro-inflammatory role for platelets in the periodontium. Using an animal model of experimental periodontitis, Coimbra and colleagues reported that administration of the antiplatelet drug clopidogrel significantly reduced bone loss and the size of the inflammatory infiltrate and alveolar bone loss, relative to untreated controls (Coimbra et al., 2014). The same group of researchers also reported that aspirin and clopidogrel reduced levels of the proinflammatory cytokines IL-6, TNF-alpha and thromboxane A2 levels in the same experimental disease model (Coimbra et al., 2011). Collectively, these studies indicate that supressing platelet function by antiplatelet drugs may prevent and/or reduce inflammation and the alveolar bone loss and tissue destruction seen in periodontal disease. By extension, it can be suggested that increased platelet activation may promote the progression of periodontal disease, which is plausible since platelets also express toll-like receptors (TLRs) that respond to periodontal pathogens such as Porphyromonas gingivalis (Andonegui et al., 2005; Blair et al., 2009; Gibson et al., 2007). The notion of an association between platelet activation and periodontal disease status is also corroborated by published data indicating that platelet counts and platelet activity are elevated in periodontitis patients (Al-Rasheed, 2012; Papapanagiotou et al., 2009).

In studies of human subjects, Nlcu et al reported that platelets from periodontitis patients are more sensitive to activation when incubated with the periodontal pathogens Aggregatibacter actinomycetemcomitans and Porphyromonas gingivalis (Nicu et al., 2009). Another study reported that relative to controls, periodontitis patients exhibited elevated serum levels of soluble P-selectin, a marker of activated platelets (Papapanagiotou et al., 2009) as well as increased activation of glycoprotein IIb/IIla, another marker of platelet activation (Lu and Malinauskas, 2011). Taken together, these data suggest an association between platelet activation and the severity of periodontal disease (Papapanagiotou et al., 2009). 


\section{Platelet factor 4 (PF4)}

The pro-inflammatory role of platelets is perhaps attributable to platelet factor 4 (PF4), a $7.8 \mathrm{kDa}$ cytokine that accounts for the bulk of platelet alpha ( $\alpha$ )-granule content (Lambert et al., 2007). PF4, also known as CXCL4, belongs to CXC family of pro-inflammatory chemokines (Strieter et al., 1996). Human PF4 is a 70 amino acid protein that exists as a tetramer of 4 subunits at physiological pH with high affinity for heparin (Rucinski et al., 1979). Crystallographic studies have shown that the PF4 tetramer has a spherical structure and carries a surface charge with equatorial band of negatively and positively charged poles (Kowalska et al., 2010; Stuckey et al., 1992; Zhang et al., 1994).

PF4 is synthesized in the megakaryocyte where it is packaged into alpha-granules of the nascent platelets (Deuel et al., 1981; Koseoglu and Flaumenhaft, 2013). PF4 has been shown to be chemotactic for phagocytes (Deuel et al., 1981; Lapchak et al., 2012; Zaldivar et al., 2010), promote neutrophil degranulation (Kasper and Petersen, 2011; Vandercappellen et al., 2011), and stimulate cytokine production in monocytes (Srivastava et al., 2010). Moreover, PF4 reportedly prevents apoptosis of monocytes and induces their differentiation into macrophages (Scheuerer et al., 2000). Conceivably, PF4 could promote the progression of periodontal disease since neutrophil chemotaxis (Havemose-Poulsen et al., 2006; Kantarci et al., 2003), neutrophil degranulation (Buchmann et al., 2002; Gustafsson and Åsman, 1996), and monocyte-to-macrophage differentiation (Page et al., 1997; Shapira et al., 1996; Zhou et al., 2012) are all hallmarks of periodontal inflammation.

In addition to its effects on leukocytes, PF4 is a documented chemoattractant for fibroblasts (Senior et al., 1983). Furthermore, it has been shown that PF4 can inhibit the activity of fibroblast growth factor (FGF) (Lozano et al., 2001; Perollet et al., 1998; Watson et al., 1994) which has been shown to promote gingival epithelial cell proliferation (Takayama et al., 2002) and periodontal regeneration (Murakami et al., 1999; Murakami et al., 2003; Takayama et al., 
2001) suggesting, by extension, that platelets can play a critical role in periodontal disease pathogenesis by modulating the activities of the cells in the periodontium, including fibroblasts.

\section{Statement of the problem}

Despite considerable indirect evidence supporting a role for platelets in chronic inflammation, there is presently no knowledge on the specific role of PF4 in the context of periodontal disease pathogenesis. Moreover, the precise molecular determinants of cytokine-driven MMP-1 upregulation in fibroblasts are not defined.

\section{Hypothesis}

I hypothesized that PF4, as a major (and pro-inflammatory) constituent of platelet $\alpha$-granules, would trigger an increase in collagenase (MMP-1) release from gingival fibroblasts. 


\section{Chapter Two: Platelet factor 4 (PF4) upregulates MMP-1 expression in gingival fibroblasts}

\section{Materials and methods}

\section{Reagents}

All reagents for cell culture were obtained from Life Technologies (Grand Island, NY). Antibodies against phospho-p44/42 MAP kinase (D.13.14.4E) and GAPDH (14C10) were obtained from Cell Signaling Technologies (Danvers, MA). Recombinant platelet factor 4 (PF4) was purchased from Abcam (Cambridge, MA). Secondary antibodies conjugated to horseradish peroxidase (HRP) were obtained from Cell Signaling Technologies. The MEK inhibitors PD98059 and PD184352 were purchased from Calbiochem (Billerica, MA) and Axon Medchem (Reston, VA), respectively, and dissolved in a dimethyl sulfoxide (DMSO) vehicle.

\section{Cell culture, measurement of pro-MMP-1 release, MAPK inhibition and immunoblotting}

Human gingival fibroblasts (HGFs) were isolated from healthy marginal gingiva from a healthy 18year-old female. Tissue donor provided a written informed consent, and procedures were reviewed and approved by the Office of Research Ethics of the University of British Columbia. Cells were maintained in a humidified incubator at $37^{\circ} \mathrm{C}$ with $5 \% \mathrm{CO}_{2}$ in alpha-MEM supplemented with $10 \%(\mathrm{v} / \mathrm{v})$ fetal bovine serum and $5 \%(\mathrm{v} / \mathrm{v})$ antibiotic solution and used for experiments between the $5^{\text {th }}$ and $8^{\text {th }}$ passages. Cells were seeded on to 6 -well tissue culture treated plates, and allowed to reach $90-95 \%$ confluence. Cells were serum-starved for 24 hours prior to stimulation with recombinant PF4.

To study the effect of PF4 on the release of pro-MMP-1, serum-starved HGFs were treated with recombinant PF4 at various concentrations (ranging $10-200 \mathrm{ng} / \mathrm{mL}$ ) and for various incubation times (ranging from 30 minutes to 6 hours). The media was then harvested and centrifuged at $4^{\circ} \mathrm{C}$. The concentration of pro-MMP-1 in the supernatants was determined by 
enzyme-linked immunosorbent assay (R \& D Systems, Minneapolis, MN). In some experiments, cells were pre-treated for 1 hour with the cell-permeant inhibitor PD98059 (50 $\mu \mathrm{M})$ to block the MAP kinase signaling pathway prior to the addition of PF4. Pro-MMP-1 release from HGFs was measured after 3 hours of incubation with PF4.

After media collection, cells were immediately washed with ice-cold phosphate-buffered saline (PBS) and solubilized in ice-cold lysis buffer. Cell lysates were clarified by centrifugation at $4^{\circ} \mathrm{C}$. Protein samples were resolved by SDS-PAGE and transferred onto polyvinylidene fluoride (PVDF) membranes. Membranes were blocked and then probed overnight at $4^{\circ} \mathrm{C}$ with an antibody against phospho-p44/42 MAPK (at a 1:2000 dilution in TBS-Tween). As a loading control, membranes were also probed with an antibody against GAPDH (1:1000 dilution in TBSTween).

\section{Quantitative polymerase chain reaction (qPCR)}

To evaluate the effect of PF4 on MMP-1 gene expression, serum-starved HGFs were cultured in the presence of PF4 (100 ng/mL) for 3 hours; HGFs cultured with vehicle alone served as a negative control. Real-time PCR was performed according to MIQE guidelines as described in detail previously (Bustin et al., 2009). Briefly, total RNA was isolated using a PureLink RNA mini kit in accordance with manufacturer's protocol (Life Technologies). Next, total RNA $(1 \mu \mathrm{g})$ was reverse transcribed using iScript Select cDNA Synthesis Kit (Bio-Rad, Mississauga, ON, Canada) and random oligodeoxynucleotide primers as per manufacturer's instructions. The realtime PCR was performed using primers for MMP-1 (Bi et al., 2016) and using alpha-1,2mannosyltranferase (ALG9), glyceraldehyde-3-phosphate dehydrogenase (GAPDH) and beta-2microglobulin (B2M) as reference genes (Tarzemany et al., 2015). All PCR primers were synthesized by Integrated DNA Technologies (Coralville, IA). Real-time PCR amplification was performed using the CFX96 System (Bio-Rad) according to the following protocol: 1 cycle at $94^{\circ} \mathrm{C}$ for 3 minutes followed by 35 cycles at $94^{\circ} \mathrm{C}$ for 10 seconds, $60^{\circ} \mathrm{C}$ for 20 seconds and 
reaction completion with reading plate followed by melt curve analysis from $65^{\circ} \mathrm{C}$ to $95^{\circ} \mathrm{C}, 5$ seconds each at $0.5^{\circ} \mathrm{C}$. Non-transcribed RNA samples served as negative controls. Each PCR reaction was performed in triplicate. Following analysis, data was processed using the comparative Ct method (CFX Manager Software Version 2.1, Bio-Rad).

\section{Statistical analysis}

The Student's t-test was used for comparisons involving only 2 groups. For the dose-response, time-course and inhibition experiments, a one-way analysis of variance (ANOVA) and Bonferroni post-hoc multiple comparison tests were used to evaluate the effects of PF4 treatment and/or MAPK inhibition on pro-MMP-1 release from HGFs. Values obtained from RTqPCR by the comparative Ct method were log2 transformed for statistical testing. Statistical significance was set at $p<0.05$. For statistical testing, each experiment was repeated a minimum of three times. 


\section{Results}

\section{Platelet factor 4 (PF4) amplifies the release of MMP-1 from gingival fibroblasts}

To evaluate how platelet-derived cytokines modulate the function of resident periodontal cells, I used human gingival fibroblasts (HGFs) cultured in the presence or absence of recombinant platelet factor 4 (PF4). The baseline concentration of pro-MMP-1 in the untreated HGF cultures was $0.90 \pm 0.17 \mathrm{ng} / \mathrm{mL}$ (mean $\pm \mathrm{SD}, \mathrm{n}=3$ ). The effect of PF4 on pro-MMP-1 release by HGFs was quantified by ELISA. I first evaluated the dose-response relationship between PF4 concentration and pro-MMP-1 secretion (Fig. 9). Over the range of concentrations tested (10$200 \mathrm{ng} / \mathrm{mL}$ ), PF4 induced a linear 0.5-to-3-fold increase in pro-MMP-1 release from HGFs, compared to untreated controls, although this was not statistically significant when the Bonferroni correction was applied to the analysis comparing all 6 test groups simultaneously (Fig. 9). Similarly, our time course data show that PF4 (100 ng/mL) triggers a significant $(p<0.05)$ and linear increase of pro-MMP-1 release over the 6-hour test period (Fig. 10).

\section{PF4 increases MMP-1 gene transcription and protein expression}

I then wished to determine whether the PF4 increases mRNA transcription of the MMP-1 gene or whether PF4 affects the exocytosis machinery of the fibroblast to enhance secretion. I used real-time PCR to quantify MMP-1 messenger RNA (mRNA) in HGFs cultured in the presence or absence of PF4. Cells treated with PF4 (100 ng/mL for 2 hours) showed a 3-fold increase $(p<0.001)$ in MMP-1 gene transcription relative to untreated controls (Fig. 11). These data suggest that PF4 targets the fibroblast's transcription machinery to enhance MMP-1 production rather than promote MMP-1 secretion through increased exocytosis.

\section{PF4 augments p44/42 MAP kinase signaling in human gingival fibroblasts}

Published data show that expression of the MMP-1 gene is controlled by the p44/42 MAP kinase (ERK) signaling pathway (Reuben et al., 2002). The activity of p44/42 MAPK is 
determined by its phosphorylation status (Roux and Blenis, 2004). To test the hypothesis that PF4 targets p44/42 to modulate MMP-1 expression, I used Western blotting to compare the levels of phosphorylated p44/42 (at threonine 202 and tyrosine 204) in HGFs cultured with and without PF4. Levels of phosphorylated p44/42 in the HGFs underwent a clear increase following PF4 treatment (Fig. 12A). To test the significance of this finding with regards to pro-MMP-1 release, I employed the cell-permeant compound PD98059, which inhibits p44/42 MAPK (ERK1/2) by blocking the upstream MAPK kinase MEK1 (Cuenda and Alessi, 2000). In human gingival fibroblasts pre-treated with $50 \mu \mathrm{M}$ of PD98059, PF4 did not induce a significantly $(p>0.05)$ greater release of pro-MMP-1 relative to untreated controls (Fig. 12B). To confirm the role of MEK/ERK signaling in the transcriptional upregulation of MMP-1, I cultured HGFs pretreated for 1 hour with PD184352 (Axon Medchem, Reston, VA), another MEK1 inhibitor (Allen et al., 2003). Consistent with the ELISA data, inhibition of the MEK/ERK signaling module by PD184352 $(2 \mu \mathrm{M})$ completely nullified the PF4-induced increase in MMP-1 gene expression (Fig. 12C). These concordant results obtained with 2 different MEK1 inhibitors collectively indicate that PF4 targets the p44/42 signaling pathway to regulate MMP-1 expression. 


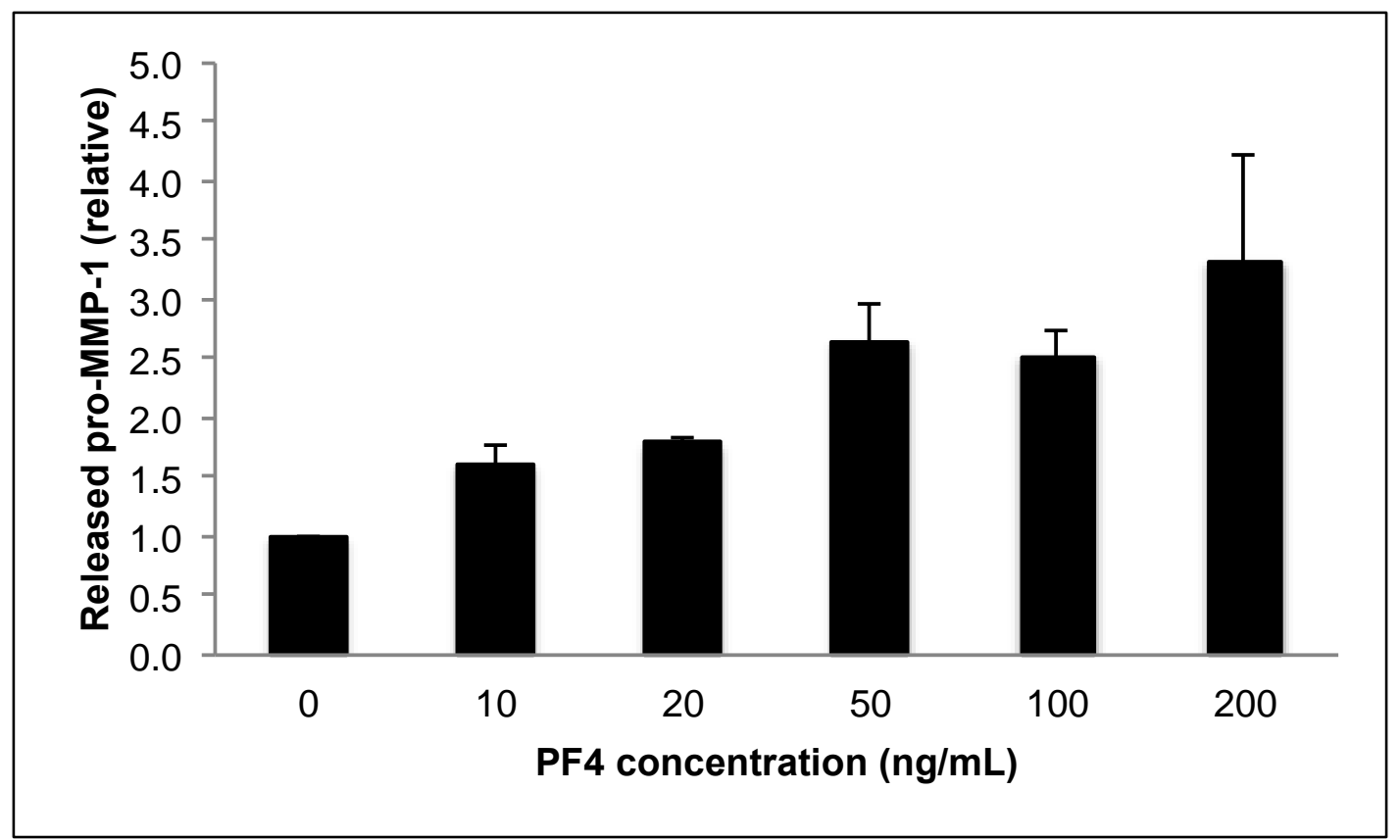

Figure 9. Dose-response relationship between platelet factor 4 (PF4) treatment and pro-MMP-1 secretion from cultured human gingival fibroblasts. Bar graph illustrates ELISA-analysis of the release of pro-MMP-1 from cultured human gingival fibroblasts treated with increasing concentrations of PF4 for 4 hours. Data are expressed as mean $\pm \mathrm{SD}$ with the control (untreated) cells set at 1, and are based on 3 independent experiments. 


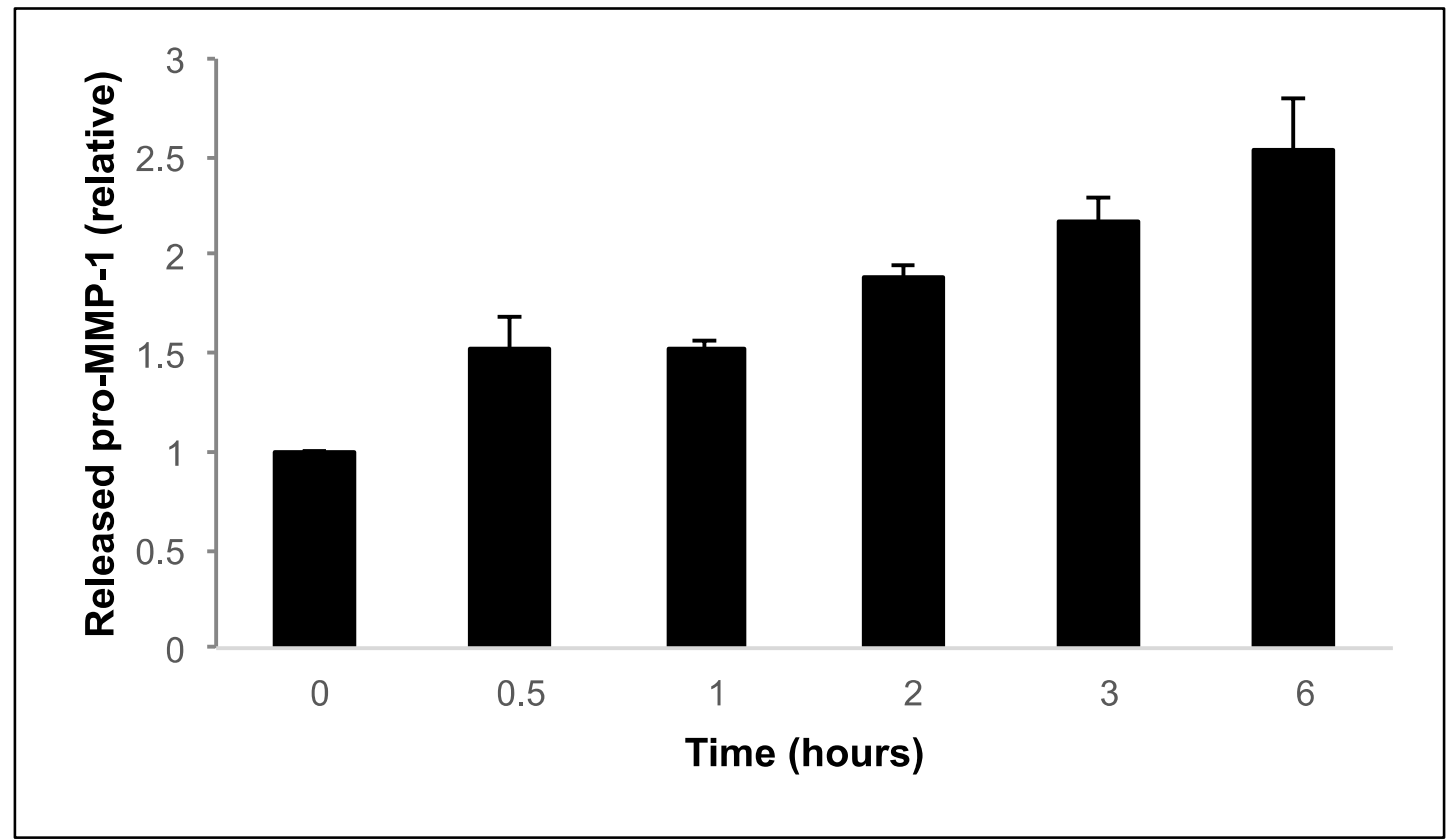

Figure 10. Time-dependent effects of platelet factor 4 (PF4) on pro-MMP-1 secretion from human gingival fibroblasts. Bar graph illustrates ELISA analysis of the release of pro-MMP-1 from cultured human gingival fibroblasts treated with recombinant PF4 (100 ng/mL) for time periods ranging from 0-6 hours. Data are expressed as mean $\pm \mathrm{SD}$ with the untreated control (time $=0$ ) cells set at 1 , and are based on 3 independent experiments. *, $\mathrm{p}<0.05 ;{ }^{* * *}, \mathrm{p}<0.0001$, based on Bonferroni multiple comparison tests. 


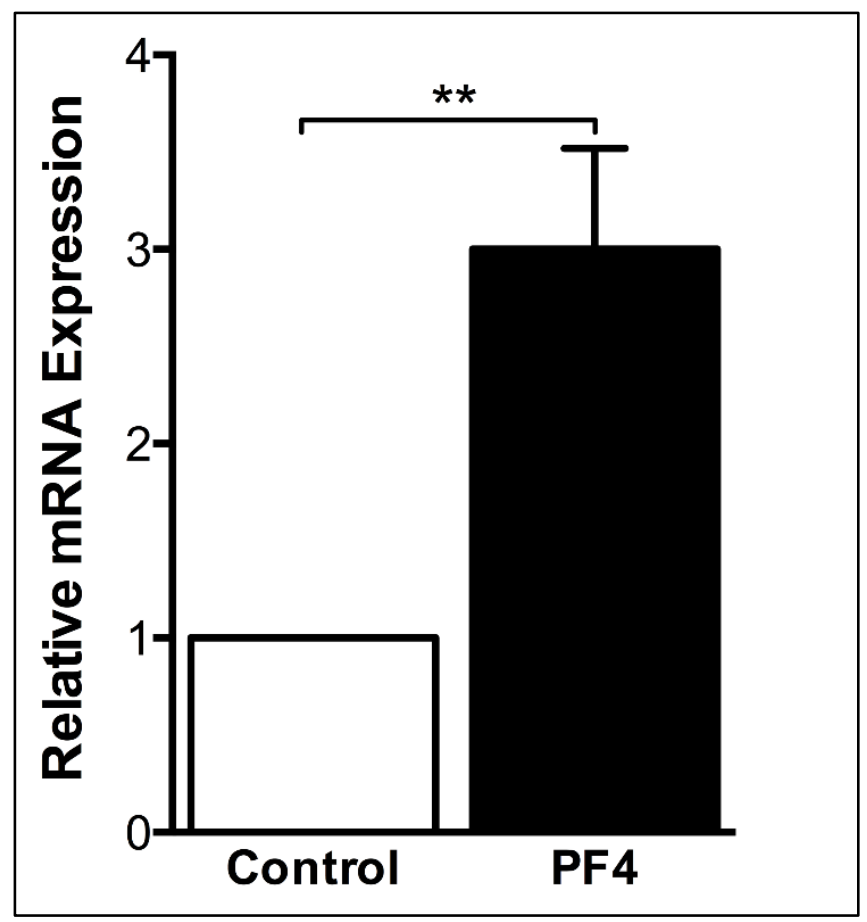

Figure 11. Platelet factor 4 (PF4) upregulates MMP-1 mRNA expression. Bar graph illustrates real-time PCR data of MMP-1 transcription in human gingival fibroblasts cultured in the absence (control, white bar) or presence (PF4, black bar) of platelet factor $4(100 \mathrm{ng} / \mathrm{mL})$ for 3 hours. Data are expressed as mean $\pm \mathrm{SD}$ with the control group set at 1 , and are based on 3 independent experiments. ${ }^{* *}, \mathrm{p}<0.01$ (Student's t-test). 
IB: Phospho-p44/42 MAPK

IB: GAPDH (loading control)
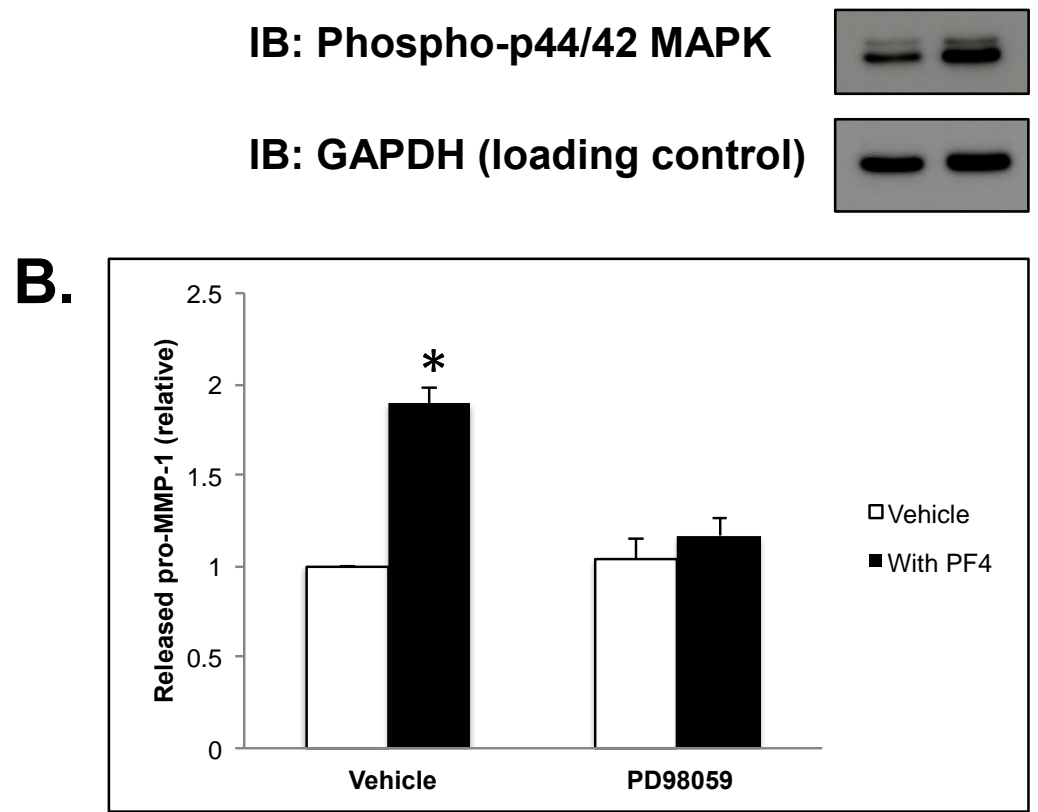

C.

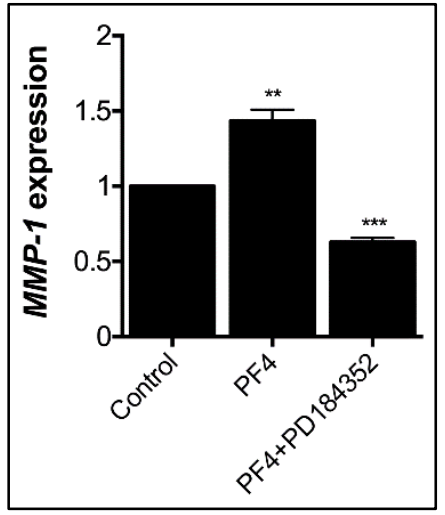

Figure 12. The PF4-induced production of pro-MMP-1 is regulated through $\mathrm{p44/42}$

MAP kinase signaling. A. Equal amounts of protein lysates of human gingival fibroblasts treated with either vehicle (-) or PF4 (+) $(100 \mathrm{ng} / \mathrm{mL})$ were resolved by SDS-PAGE.

Western blot illustrates increased phosphorylation of p44/42 MAP kinase following PF4 treatment. GAPDH is shown as a loading control. B. Histogram illustrates the PF4induced release of pro-MMP-1 (as assessed by ELISA) in cultured human gingival fibroblasts pre-treated with either vehicle ( $0.1 \%$ DMSO, white bars) or with the inhibitor PD98059 (black bars). Data are expressed as mean \pm SD with the vehicle-treated control cells set at 1 , and are based on 3 independent experiments. *, $\mathrm{p}<0.01$, based on Bonferroni multiple comparison tests. C. Bar graph illustrates the real-time PCR data of MMP-1 transcription in vehicle-treated control HGFs (control), vehicle-treated HGFs cultured in the presence of PF4 (PF4), and HGFs pre-treated with the inhibitor PD184352 $(2 \mu \mathrm{M})$ for 1 hour prior to stimulation and incubation with PF4. Data are expressed as mean $\pm \mathrm{SD}$ with the vehicle-treated control cells set at 1 , and are based on 3 independent experiments. **, $\mathrm{p}<0.01 ; * * *, \mathrm{p}<0.001$, based on Bonferroni multiple comparison tests. 


\section{Discussion}

Platelets are emerging as key contributors to chronic inflammation (Duerschmied et al., 2014; Jenne et al., 2013; Semple and Freedman, 2010) although their role in the pathogenesis of periodontitis is not well understood. In the present study, I observed that cultured human gingival fibroblasts treated with PF4 produced up to 3 times more MMP-1 relative to controls. It should be noted that I simultaneously tested six (6) different concentrations of PF4 and applied the Bonferroni correction to compensate for multiple comparisons. Consequently, individual differences between groups did not reach statistical significance within our comprehensive analysis. This point notwithstanding, our central finding is validated by the consistency of the results I obtained from two independent and quantitative experimental approaches: ELISA analysis of secreted pro-MMP-1 and real-time PCR. Other pro-inflammatory cytokines such as interleukin-1 (IL-1) and tumor necrosis factor-alpha (TNF- $\alpha$ ) are extensively documented in terms of their upregulation of MMP-1 expression in human gingival fibroblasts (Domeij et al., 2002; Tewari et al., 1994). However, the present study is the first to identify a function for PF4 in MMP-1 expression, thus introducing a previously unidentified role for platelet-derived cytokines in gene transcription. The PF4-induced MMP-1 expression is likely via a direct effect as it occurred within the first few hours after treatment. The physiologic concentration of PF4 in plasma is reported to be less than $10 \mathrm{ng} / \mathrm{mL}$ (Zucker and Katz, 1991). Our dose-response data show that pro-MMP-1 release was amplified by more than $50 \%$ at only slightly supra-physiologic concentrations of PF4 although this difference was not statistically significant in the context of our analysis. This finding nonetheless underscores PF4's potency as a pro-inflammatory mediator.

The importance of HGF-derived MMP-1 with respect to periodontal disease progression is well known (Sapna et al., 2014), as is the role of MAP kinase signaling in the induction of MMP1 gene expression (Huntington et al., 2004; Vincenti and Brinckerhoff, 2002). I found that p44/42 
(ERK) phosphorylation was amplified by PF4 treatment, which is consistent with a recent report of increased ERK phosphorylation in PF4-treated lymphoblasts (Van Raemdonck et al., 2014). I confirmed the importance of p44/42 (ERK1/2) activation in pro-MMP-1 delivery since pro-MMP1 secretion was attenuated by the MEK inhibitor PD98059. Similarly, blockade of MAP kinase signaling also abrogated PF4-driven increases in MMP-1 gene transcription. These data are consistent with published reports that p44/42 MAPK activation is responsible for MMP-1 expression (Reuben et al., 2002). Taken together, our findings delineate a novel PF4- and ERKdriven pathway for MMP-1 expression in HGFs.

Our findings suggest that platelet activation promotes periodontal tissue degradation by stimulating MMP-1 production by gingival fibroblasts. These data could at least partially explain recent reports of elevated platelet counts (Al-Rasheed, 2012; Kumar et al., 2014) and increased platelet activation (Nicu et al., 2009; Papapanagiotou et al., 2009) in patients with chronic periodontitis. Conceivably, higher numbers of circulating and highly reactive platelets would release greater amounts of PF4 that would in turn potentiate MMP-1 production and release from gingival fibroblasts. In this context, increased PF4 secretion from platelets would be especially plausible in periodontitis patients given that platelets are directly activated by periodontal pathogens (Assinger et al., 2011; Yu et al., 2011).

One limitation of the present study is that a receptor for the PF4 ligand is not identified. Potential candidate receptors could include receptor tyrosine kinases or G-protein coupled receptors since these are known effectors of the MAP kinase pathway (Delcourt et al., 2007; Natarajan and Berk, 2006). Further research is required to definitively elucidate the mechanism(s) by which PF4 activates MAP kinases. In conclusion, the present study describes a PF4-mediated upregulation of MMP-1 in human gingival fibroblasts. From a broader perspective, this finding points to a previously unidentified role for platelets in the progression of periodontitis while yielding a novel insight into crosstalk between platelets and fibroblasts. 


\section{Chapter Three: Conclusions and future directions}

\section{Conclusions:}

The present study is the first to show a role for a platelet-derived cytokine PF4 in upregulating MMP-1 expression in human gingival fibroblasts. Our data also demonstrate a PF4-driven increase in p44/42 (ERK) phosphorylation, suggesting a novel mechanism for platelet-induced activation of MAP kinase signaling.

\section{Directions for future work:}

1. While our study indicates that PF4 activates MEK/ERK module of the MAP kinase signaling pathway, the cell surface receptor for PF4 has not been identified. Possible candidate receptors include G-protein coupled receptors (GPCRs) and receptor tyrosine kinases (RTKs) as they have been shown to be effectors of MAP kinase pathway (Delcourt et al., 2007; Natarajan and Berk, 2006). One approach towards identifying the PF4 receptor could involve preparing purified plasma membrane (PM) lysate fractions from gingival fibroblasts. Recombinant PF4 bound to a resin bead matrix could then be used to pull down PF4 binding partner protein(s) present in the cell membrane.

2. The physiologic relevance of PF4-binding partner proteins in the context of MMP-1 production could be tested by knockout or siRNA-mediated knockdown of the protein(s) in question. Control and siRNA-treated gingival fibroblasts would be treated with recombinant PF4 to evaluate the resultant effect on MMP-1 transcription and/or secretion.

3. The findings of our study imply that platelet activation would promote periodontal tissue destruction by increasing MMP-1 production in gingival fibroblasts. This notion is consistent 
with recent reports of increased platelet counts and activity in chronic periodontitis patients (Al-Rasheed, 2012; Kumar et al., 2014). Given that platelets are directly activated by periodontal pathogens (Assinger et al., 2011; Yu et al., 2011), it would be of interest to quantify circulating PF4 concentrations in humans with chronic periodontitis, as well as healthy controls. 


\section{BIBLIOGRAPHY:}

Achong, R., I. Nishimura, H. Ramachandran, T.H. Howell, J.P. Fiorellini, and N.Y. Karimbux. 2003. Membrane type (MT) 1-matrix metalloproteinase (MMP) and MMP-2 expression in ligature-induced periodontitis in the rat. Journal of periodontology. 74:494-500.

Al-Rasheed, A. 2012. Elevation of white blood cells and platelet counts in patients having chronic periodontitis. Saudi Dent J. 24:17-21.

Allen, L.F., J. Sebolt-Leopold, and M.B. Meyer. 2003. Cl-1040 (PD184352), a targeted signal transduction inhibitor of MEK (MAPKK). Semin Oncol. 30:105-116.

Andonegui, G., S.M. Kerfoot, K. McNagny, K.V. Ebbert, K.D. Patel, and P. Kubes. 2005. Platelets express functional Toll-like receptor-4. Blood. 106:2417-2423.

Ara, T., K. Kurata, K. Hirai, T. Uchihashi, T. Uematsu, Y. Imamura, K. Furusawa, S. Kurihara, and P.L. Wang. 2009. Human gingival fibroblasts are critical in sustaining inflammation in periodontal disease. Journal of periodontal research. 44:21-27.

Assinger, A., E. Buchberger, M. Laky, A. Esfandeyari, C. Brostjan, and I. Volf. 2011. Periodontopathogens induce soluble P-selectin release by endothelial cells and platelets. Thromb Res. 127:e20-26.

Assoian, R.K., and M.B. Sporn. 1986. Type beta transforming growth factor in human platelets: release during platelet degranulation and action on vascular smooth muscle cells. The Journal of cell biology. 102:1217-1223.

Astolfi, C.M., A.L. Shinohara, R.A. Da Silva, M.C.L.G. Santos, S.R.P. Line, and A.P. De Souza. 2006. Genetic polymorphisms in the MMP-1 and MMP-3 gene may contribute to chronic periodontitis in a Brazilian population. Journal of clinical periodontology. 33:699-703.

Baker, B., J.M. Ovigne, A. Powles, S. Corcoran, and L. Fry. 2003. Normal keratinocytes express toll-like receptors (TLRs) 1, 2 and 5: modulation of TLR expression in chronic plaque psoriasis. British Journal of Dermatology. 148:670-679.

Battinelli, E.M., B.A. Markens, and J.E. Italiano. 2011. Release of angiogenesis regulatory proteins from platelet alpha granules: modulation of physiologic and pathologic angiogenesis. Blood. 118:1359-1369.

Bauer, J., C. Huy, J. Brenmoehl, F. Obermeier, and J. Bock. 2009. Matrix metalloproteinase-1 expression induced by IL-1 $\beta$ requires acid sphingomyelinase. FEBS letters. 583:915920.

Bauvois, B. 2012. New facets of matrix metalloproteinases MMP-2 and MMP-9 as cell surface transducers: outside-in signaling and relationship to tumor progression. Biochimica et Biophysica Acta (BBA)-Reviews on Cancer. 1825:29-36.

Beklen, A., M. Ainola, M. Hukkanen, C. Gürgan, T. Sorsa, and Y. Konttinen. 2007. MMPs, IL-1, and TNF are regulated by IL-17 in periodontitis. Journal of dental research. 86:347-351.

Berkovitz, B.K., G.R. Holland, and B.J. Moxham. 2009. Oral anatomy, histology and embryology. Mosby.

Bi, J., L. Koivisto, G. Owen, P. Huang, Z. Wang, Y. Shen, L. Bi, A. Rokka, M. Haapasalo, J. Heino, L. Hakkinen, and H.S. Larjava. 2016. Epithelial Microvesicles Promote an Inflammatory Phenotype in Fibroblasts. Journal of dental research. 95:680-688.

Birkedal-Hansen, H. 1993. Role of Matrix Metalloproteinases in Human Periodontal Diseases*. Journal of periodontology. 64:474-484.

Blair, P., S. Rex, O. Vitseva, L. Beaulieu, K. Tanriverdi, S. Chakrabarti, C. Hayashi, C.A. Genco, M. lafrati, and J.E. Freedman. 2009. Stimulation of Toll-like receptor 2 in human platelets induces a thromboinflammatory response through activation of phosphoinositide 3kinase. Circulation research. 104:346-354. 
Bonfanti, L., A.A. Mironov, J.A. Martínez-Menárguez, O. Martella, A. Fusella, M. Baldassarre, R. Buccione, H.J. Geuze, and A. Luini. 1998. Procollagen traverses the Golgi stack without leaving the lumen of cisternae: evidence for cisternal maturation. Cell. 95:993-1003.

Bozkurt, S.B., S.S. Hakki, E.E. Hakki, Y. Durak, and A. Kantarci. 2016. Porphyromonas gingivalis Lipopolysaccharide Induces a Pro-inflammatory Human Gingival Fibroblast Phenotype. Inflammation:1-10.

Brew, K., and H. Nagase. 2010. The tissue inhibitors of metalloproteinases (TIMPs): an ancient family with structural and functional diversity. Biochimica et Biophysica Acta (BBA)Molecular Cell Research. 1803:55-71.

Brooks, A.J., W. Dai, M.L. O’Mara, D. Abankwa, Y. Chhabra, R.A. Pelekanos, O. Gardon, K.A. Tunny, K.M. Blucher, and C.J. Morton. 2014. Mechanism of activation of protein kinase JAK2 by the growth hormone receptor. Science. 344:1249783.

Buchmann, R., A. Hasilik, T. Van Dyke, and D. Lange. 2002. Amplified crevicular leukocyte activity in aggressive periodontal disease. Journal of dental research. 81:716-721.

Bustin, S.A., V. Benes, J.A. Garson, J. Hellemans, J. Huggett, M. Kubista, R. Mueller, T. Nolan, M.W. Pfaffl, G.L. Shipley, J. Vandesompele, and C.T. Wittwer. 2009. The MIQE guidelines: minimum information for publication of quantitative real-time PCR experiments. Clin Chem. 55:611-622.

Caton, J.G., S.G. Ciancio, T.M. Blieden, M. Bradshaw, R.J. Crout, A.F. Hefti, J.M. Massaro, A.M. Polson, J. Thomas, and C. Walker. 2000. Treatment with subantimicrobial dose doxycycline improves the efficacy of scaling and root planing in patients with adult periodontitis. Journal of periodontology. 71:521-532.

Chakraborti, S., M. Mandal, S. Das, A. Mandal, and T. Chakraborti. 2003. Regulation of matrix metalloproteinases: an overview. Molecular and cellular biochemistry. 253:269-285.

Chandra, S., S. Chandra, M. Chandra, and N. Chandra. 2004. Textbook of Dental and Oral Histology and Embryology with MCQs. Jaypee Brothers, Medical Publishers: India.

Chen, D., A.M. Bernstein, P.P. Lemons, and S.W. Whiteheart. 2000. Molecular mechanisms of platelet exocytosis: role of SNAP-23 and syntaxin 2 in dense core granule release. Blood. 95:921-929.

Chen, H., D. Li, T. Saldeen, and J.L. Mehta. 2003. TGF- $\beta 1$ attenuates myocardial ischemiareperfusion injury via inhibition of upregulation of MMP-1. American Journal of Physiology-Heart and Circulatory Physiology. 284:H1612-H1617.

Chen, J.-J., J.-F. Huang, W.-X. Du, and P.-J. Tong. 2014. Expression and significance of MMP3 in synovium of knee joint at different stage in osteoarthritis patients. Asian Pacific journal of tropical medicine. 7:297-300.

Cifcibasi, E., A. Kantarci, S. Badur, H. Issever, and S. Cintan. 2015. Impact of metronidazole and amoxicillin combination on matrix metalloproteinases-1 and tissue inhibitors of matrix metalloproteinases balance in generalized aggressive periodontitis. European journal of dentistry. 9:53.

Coimbra, L., J. Steffens, M. Muscará, C. Rossa, and L.C. Spolidorio. 2014. Antiplatelet drugs reduce the immunoinflammatory response in a rat model of periodontal disease. Journal of periodontal research. 49:729-735.

Coimbra, L.S., C. Rossa Jr, M.R. Guimaraes, R.F. Gerlach, M.N. Muscara, D.M. Spolidorio, B.S. Herrera, and L.C. Spolidorio. 2011. Influence of antiplatelet drugs in the pathogenesis of experimental periodontitis and periodontal repair in rats. Journal of periodontology. 82:767-777.

Cooper, G.M., and D. Ganem. 1997. The Cell: A Molecular Approach. Nature Medicine. 3:10421042.

Crout, R., H. Lee, K. Schroeder, H.y.c. Crout, N. Ramamurthy, M. Wiener, and L. Golub. 1996. The "cyclic" regimen of low-dose doxycycline for adult periodontitis: a preliminary study. Journal of periodontology. 67:506-514. 
Cuenda, A., and D.R. Alessi. 2000. Use of kinase inhibitors to dissect signaling pathways. Methods Mol Biol. 99:161-175.

Danese, S., L. Motte Cd Cde, and C. Fiocchi. 2004. Platelets in inflammatory bowel disease: clinical, pathogenic, and therapeutic implications. Am J Gastroenterol. 99:938-945.

Darnell Jr, J.E., I.M. Kerr, and G.R. Stark. 1994. Jak-STAT pathways and transcriptional activation in response to IFNs and other extracellular signaling proteins. Science-AAASweekly paper edition-including guide to scientific information. 264:1415-1420.

Darveau, R.P., T.-T.T. Pham, K. Lemley, R.A. Reife, B.W. Bainbridge, S.R. Coats, W.N. Howald, S.S. Way, and A.M. Hajjar. 2004. Porphyromonas gingivalis lipopolysaccharide contains multiple lipid A species that functionally interact with both toll-like receptors 2 and 4. Infection and immunity. 72:5041-5051.

De Souza, A., P. Trevilatto, R. Scarel-Caminaga, R. Brito, and S. Line. 2003. MMP-1 promoter polymorphism: association with chronic periodontitis severity in a Brazilian population. Journal of clinical periodontology. 30:154-158.

DeCarlo, A.A., H.E. Grenett, G.J. Harber, L.J. Windsor, M.K. Bodden, B. Birkedal-Hansen, and $\mathrm{H}$. Birkedal-Hansen. 1998. Induction of matrix metalloproteinases and a collagendegrading phenotype in fibroblasts and epithelial cells by secreted Porphyromonas gingivalis proteinase. Journal of periodontal research. 33:408-420.

Delcourt, N., J. Bockaert, and P. Marin. 2007. GPCR-jacking: from a new route in RTK signalling to a new concept in GPCR activation. Trends Pharmacol Sci. 28:602-607.

Desarda, H., and S. Gaikwad. 2013. Matrix metalloproteinases and implication in periodontitis-A short review. J Dent Allied Sci. 2:66-70.

Deuel, T.F., R.M. Senior, D. Chang, G.L. Griffin, R.L. Heinrikson, and E.T. Kaiser. 1981. Platelet factor 4 is chemotactic for neutrophils and monocytes. Proceedings of the National Academy of Sciences. 78:4584-4587.

Domeij, H., T. Yucel-Lindberg, and T. Modeer. 2002. Signal pathways involved in the production of MMP-1 and MMP-3 in human gingival fibroblasts. Eur J Oral Sci. 110:302-306.

Duerschmied, D., C. Bode, and I. Ahrens. 2014. Immune functions of platelets. Thrombosis and haemostasis. 112:678-691.

Dufour, A., N.S. Sampson, S. Zucker, and J. Cao. 2008. Role of the hemopexin domain of matrix metalloproteinases in cell migration. Journal of cellular physiology. 217:643-651.

Ebbe, S., F. Stohlman, J. Donovan, and D. Howard. 1965. Megakaryocytopoiesis in the rat. Blood. 26:20-35.

Eke, P.I., B.A. Dye, L. Wei, G.D. Slade, G.O. Thornton-Evans, W.S. Borgnakke, G.W. Taylor, R.C. Page, J.D. Beck, and R.J. Genco. 2015. Update on Prevalence of Periodontitis in Adults in the United States: NHANES 2009 to 2012. Journal of periodontology. 86:611622.

Elkington, P., T. Shiomi, R. Breen, R.K. Nuttall, C.A. Ugarte-Gil, N.F. Walker, L. Saraiva, B. Pedersen, F. Mauri, and M. Lipman. 2011. MMP-1 drives immunopathology in human tuberculosis and transgenic mice. The Journal of clinical investigation. 121:1827-1833.

Emingil, G., G. Atilla, T. Sorsa, H. Luoto, L. Kirilmaz, and H. Baylas. 2004. The effect of adjunctive low-dose doxycycline therapy on clinical parameters and gingival crevicular fluid matrix metalloproteinase-8 levels in chronic periodontitis. Journal of periodontology. 75:106-115.

Escolar, G., and J. White. 1990. The platelet open canalicular system: a final common pathway. Blood cells. 17:467-485; discussion 486-495.

Gao, D., and C. Bing. 2011. Macrophage-induced expression and release of matrix metalloproteinase 1 and 3 by human preadipocytes is mediated by IL-1 $\beta$ via activation of MAPK signaling. Journal of cellular physiology. 226:2869-2880. 
Garlet, G.P., W. Martins, B.A. Fonseca, B.R. Ferreira, and J.S. Silva. 2004. Matrix metalloproteinases, their physiological inhibitors and osteoclast factors are differentially regulated by the cytokine profile in human periodontal disease. Journal of clinical periodontology. 31:671-679.

Garnero, P., O. Borel, E. Gineyts, F. Duboeuf, H. Solberg, M.L. Bouxsein, C. Christiansen, and P.D. Delmas. 2006. Extracellular post-translational modifications of collagen are major determinants of biomechanical properties of fetal bovine cortical bone. Bone. 38:300309.

Gibson, I., C. Frank, and C.A. Genco. 2007. Porphyromonas gingivalis mediated periodontal disease and atherosclerosis: disparate diseases with commonalities in pathogenesis through TLRs. Current pharmaceutical design. 13:3665-3675.

Glasheen, B.M., A.T. Kabra, and A. Page-McCaw. 2009. Distinct functions for the catalytic and hemopexin domains of a Drosophila matrix metalloproteinase. Proceedings of the National Academy of Sciences. 106:2659-2664.

Glick, B.S., and V. Malhotra. 1998. The curious status of the Golgi apparatus. Cell. 95:883-889.

Gnatenko, D.V., J.J. Dunn, S.R. McCorkle, D. Weissmann, P.L. Perrotta, and W.F. Bahou. 2003. Transcript profiling of human platelets using microarray and serial analysis of gene expression. Blood. 101:2285-2293.

Golub, L., H.-M. Lee, M. Ryan, W. Giannobile, J. Payne, and T. Sorsa. 1998. Tetracyclines inhibit connective tissue breakdown by multiple non-antimicrobial mechanisms. Advances in dental research. 12:12-26.

Golubkov, V.S., P. Cieplak, A.V. Chekanov, B.I. Ratnikov, A.E. Aleshin, N.V. Golubkova, T.I. Postnova, I.A. Radichev, D.V. Rozanov, and W. Zhu. 2010. Internal cleavages of the autoinhibitory prodomain are required for membrane type 1 matrix metalloproteinase activation, although furin cleavage alone generates inactive proteinase. Journal of Biological Chemistry. 285:27726-27736.

Gonçalves, P.F., H. Huang, S. McAninley, B. Alfant, P. Harrison, I. Aukhil, C. Walker, and L.M. Shaddox. 2013. Periodontal treatment reduces matrix metalloproteinase levels in localized aggressive periodontitis. Journal of periodontology. 84:1801-1808.

Guan, S.-M., L. Shu, S.-M. Fu, B. Liu, X.-L. Xu, and J.-Z. Wu. 2009. Prevotella intermedia upregulates MMP-1 and MMP-8 expression in human periodontal ligament cells. FEMS microbiology letters. 299:214-222.

Gursoy, U., E. Könönen, and V.J. Uitto. 2008. Stimulation of epithelial cell matrix metalloproteinase (MMP-2,-9,-13) and interleukin-8 secretion by fusobacteria. Oral microbiology and immunology. 23:432-434.

Gustafsson, A., and B. Åsman. 1996. Increased release of free oxygen radicals from peripheral neutrophils in adult periodontitis after Fey-receptor stimulation. Journal of clinical periodontology. 23:38-44.

Hanes, P.J., and R. Krishna. 2010. Characteristics of inflammation common to both diabetes and periodontitis: are predictive diagnosis and targeted preventive measures possible? The EPMA journal. 1:101-116.

Harrison, P., and A.H. Goodall. 2008. "Message in the Platelet"-more than just vestigial mRNA! Platelets. 19:395-404.

Hartwig, J.H. 2002. Platelet structure. Platelets. 1:26.

Harvey, R.A., and D.R. Ferrier. 2011. Biochemistry. Lippincott Williams \& Wilkins.

Havemose-Poulsen, A., J. Westergaard, K. Stoltze, H. Skjødt, B. Danneskiold-Samsøe, H. Locht, K. Bendtzen, and P. Holmstrup. 2006. Periodontal and hematological characteristics associated with aggressive periodontitis, juvenile idiopathic arthritis, and rheumatoid arthritis. Journal of periodontology. 77:280-288.

Hay, E.D. 2013. Cell biology of extracellular matrix. Springer Science \& Business Media. 
Hayashi, F., T.K. Means, and A.D. Luster. 2003. Toll-like receptors stimulate human neutrophil function. Blood. 102:2660-2669.

Heemskerk, J., and S. Sage. 1994. Calcium signalling in platelets and other cells. Platelets. 5:295-316.

Hernández, M., B. Martínez, J.M. Tejerina, M.A. Valenzuela, and J. Gamonal. 2007. MMP-13 and TIMP-1 determinations in progressive chronic periodontitis. Journal of clinical periodontology. 34:729-735.

Hernandez, M., M.A. Valenzuela, C. Lopez-Otin, J. Alvarez, J.M. Lopez, R. Vernal, and J. Gamonal. 2006. Matrix metalloproteinase-13 is highly expressed in destructive periodontal disease activity. Journal of periodontology. 77:1863-1870.

Hu, J., P.E. Van den Steen, Q.-X.A. Sang, and G. Opdenakker. 2007. Matrix metalloproteinase inhibitors as therapy for inflammatory and vascular diseases. Nature reviews Drug discovery. 6:480-498.

Huang, G.J., S.K. Haake, J.W. Kim, and N.H. Park. 1998. Differential expression of interleukin-8 and intercellular adhesion molecule- 1 by human gingival epithelial cells in response to Actinobacillus actinomycetemcomitans or Porphyromonas gingivalis infection. Oral microbiology and immunology. 13:301-309.

Huntington, J.T., J.M. Shields, C.J. Der, C.A. Wyatt, U. Benbow, C.L. Slingluff, Jr., and C.E. Brinckerhoff. 2004. Overexpression of collagenase 1 (MMP-1) is mediated by the ERK pathway in invasive melanoma cells: role of BRAF mutation and fibroblast growth factor signaling. The Journal of biological chemistry. 279:33168-33176.

Hurst, N., D. Stocken, S. Wilson, C. Keh, M. Wakelam, and T. Ismail. 2007. Elevated serum matrix metalloproteinase 9 (MMP-9) concentration predicts the presence of colorectal neoplasia in symptomatic patients. British journal of cancer. 97:971-977.

Idzko, M., S. Pitchford, and C. Page. 2015. Role of platelets in allergic airway inflammation. $J$ Allergy Clin Immunol. 135:1416-1423.

Ingman, T., T. Sorsa, J. Michaelis, and Y.T. Konttinen. 1994. Immunohistochemical study of neutrophil-and fibroblast-type collagenases and stromelysin-1 in adult periodontitis. Eur $J$ Oral Sci. 102:342-349.

Ingman, T., T. Tervahartiala, Y. Ding, H. Tschesche, A. Haerian, D.F. Kinane, Y.T. Konttinen, and T. Sorsa. 1996. Matrix metalloproteinases and their inhibitors in gingival crevicular fluid and saliva of periodontitis patients. Journal of clinical periodontology. 23:1127-1132.

Isaksen, B., and M. Fagerhol. 2001. Calprotectin inhibits matrix metalloproteinases by sequestration of zinc. Molecular Pathology. 54:289-292.

Jeng, J.H., W.H. Lan, L.J. Hahn, C.C. Hsieh, and M.Y.P. Kuo. 1996. Inhibition of the migration, attachment, spreading, growth and collagen synthesis of human gingival fibroblasts by arecoline, a major areca alkaloid, in vitro. Journal of oral pathology \& medicine. 25:371375.

Jenne, C.N., R. Urrutia, and P. Kubes. 2013. Platelets: bridging hemostasis, inflammation, and immunity. International journal of laboratory hematology. 35:254-261.

Jezierska, A., and T. Motyl. 2009. Matrix metalloproteinase-2 involvement in breast cancer progression: a mini-review. Medical Science Monitor. 15:RA32-RA40.

Johnson, G.L., and R. Lapadat. 2002. Mitogen-activated protein kinase pathways mediated by ERK, JNK, and p38 protein kinases. Science. 298:1911-1912.

Jürgensen, H.J., D.H. Madsen, S. Ingvarsen, M.C. Melander, H. Gårdsvoll, L. Patthy, L.H. Engelholm, and N. Behrendt. 2011. A Novel Functional Role of Collagen Glycosylation INTERACTION WITH THE ENDOCYTIC COLLAGEN RECEPTOR UPARAP/ENDO180. Journal of Biological Chemistry. 286:32736-32748.

Kaden, J.J., C.-E. Dempfle, R. Grobholz, H.-T. Tran, R. Kılıç, A. Sarıkoç, M. Brueckmann, C. Vahl, S. Hagl, and K.K. Haase. 2003. Interleukin-1 beta promotes matrix 
metalloproteinase expression and cell proliferation in calcific aortic valve stenosis. Atherosclerosis. 170:205-211.

Kaku, M., and M. Yamauchi. 2014. Mechano-regulation of collagen biosynthesis in periodontal ligament. Journal of prosthodontic research. 58:193-207.

Kantarci, A., K. Oyaizu, and T.E.V. Dyke. 2003. Neutrophil-mediated tissue injury in periodontal disease pathogenesis: findings from localized aggressive periodontitis. Journal of periodontology. 74:66-75.

Kasper, B., and F. Petersen. 2011. Molecular pathways of platelet factor 4/CXCL4 signaling. European journal of cell biology. 90:521-526.

Kawai, T., and S. Akira. 2007. Signaling to NF-kB by Toll-like receptors. Trends in molecular medicine. 13:460-469.

Khokha, R., A. Murthy, and A. Weiss. 2013. Metalloproteinases and their natural inhibitors in inflammation and immunity. Nature Reviews Immunology. 13:649-665.

Kida, Y., M. Kobayashi, T. Suzuki, A. Takeshita, Y. Okamatsu, S. Hanazawa, T. Yasui, and K. Hasegawa. 2005. Interleukin-1 stimulates cytokines, prostaglandin E2 and matrix metalloproteinase-1 production via activation of MAPK/AP-1 and NF-kappaB in human gingival fibroblasts. Cytokine. 29:159-168.

Kiili, M., S. Cox, H. Chen, J. Wahlgren, P. Maisi, B. Eley, T. Salo, and T. Sorsa. 2002. Collagenase-2 (MMP-8) and collagenase-3 (MMP-13) in adult periodontitis: molecular forms and levels in gingival crevicular fluid and immunolocalisation in gingival tissue. Journal of clinical periodontology. 29:224-232.

Kim, S., S.H. Ahn, J.-S. Lee, J.-E. Song, S.-H. Cho, S. Jung, S.-K. Kim, S.-H. Kim, K.-P. Lee, and K.-S. Kwon. 2016. Differential matrix metalloprotease (MMP) expression profiles found in aged gingiva. PloS one. 11:e0158777.

Klinger, M.H., and W. Jelkmann. 2002. Review: role of blood platelets in infection and inflammation. Journal of interferon \& cytokine research. 22:913-922.

Ko, S.Y. 2012. Myricetin suppresses LPS-induced MMP expression in human gingival fibroblasts and inhibits osteoclastogenesis by downregulating NFATc1 in RANKLinduced RAW 264.7 cells. Archives of oral biology. 57:1623-1632.

Kolb, S.A., F. Lahrtz, R. Paul, D. Leppert, D. Nadal, H.-W. Pfister, and A. Fontana. 1998. Matrix metalloproteinases and tissue inhibitors of metalloproteinases in viral meningitis: upregulation of MMP-9 and TIMP-1 in cerebrospinal fluid. Journal of neuroimmunology. 84:143-150.

Korostoff, J.M., J.F. Wang, D.P. Sarment, J.C. Stewart, R.S. Feldman, and P.C. Billings. 2000. Analysis of in situ protease activity in chronic adult periodontitis patients: expression of activated MMP-2 and a $40 \mathrm{kDa}$ serine protease. Journal of periodontology. 71:353-360.

Korzus, E., H. Nagase, R. Rydell, and J. Travis. 1997. The mitogen-activated protein kinase and JAK-STAT signaling pathways are required for an oncostatin M-responsive elementmediated activation of matrix metalloproteinase 1 gene expression. The Journal of biological chemistry. 272:1188-1196.

Koseoglu, S., and R. Flaumenhaft. 2013. Advances in platelet granule biology. Current opinion in hematology. 20:464-471.

Kowalska, M.A., L. Rauova, and M. Poncz. 2010. Role of the platelet chemokine platelet factor 4 (PF4) in hemostasis and thrombosis. Thrombosis research. 125:292-296.

Krauss, G. 2006. Biochemistry of signal transduction and regulation. John Wiley \& Sons.

Kubota, T., T. Nomura, T. Takahashi, and K. Hara. 1996. Expression of mRNA for matrix metalloproteinases and tissue inhibitors of metalloproteinases in periodontitis-affected human gingival tissue. Archives of oral biology. 41:253-262.

Kucharz, E.J. 1992. Biosynthesis of collagen. In The Collagens: Biochemistry and Pathophysiology. Springer. 31-53. 
Kumada, Y., and S. Zhang. 2010. Significant type I and type III collagen production from human periodontal ligament fibroblasts in 3D peptide scaffolds without extra growth factors. PLoS One. 5:e10305.

Kumar, B.P., T. Khaitan, P. Ramaswamy, P. Sreenivasulu, G. Uday, and R.G. Velugubantla. 2014. Association of chronic periodontitis with white blood cell and platelet count - A Case Control Study. J Clin Exp Dent. 6:e214-217.

Kumar, M.S., G. Vamsi, R. Sripriya, and P.K. Sehgal. 2006. Expression of matrix metalloproteinases (MMP-8 and-9) in chronic periodontitis patients with and without diabetes mellitus. Journal of periodontology. 77:1803-1808.

Lambert, M.P., L. Rauova, M. Bailey, M.C. Sola-Visner, M.A. Kowalska, and M. Poncz. 2007. Platelet factor 4 is a negative autocrine in vivo regulator of megakaryopoiesis: clinical and therapeutic implications. Blood. 110:1153-1160.

Lapchak, P.H., A. Ioannou, P. Rani, L.A. Lieberman, K. Yoshiya, L. Kannan, J.J. Dalle Lucca, M.A. Kowalska, and G.C. Tsokos. 2012. The role of platelet factor 4 in local and remote tissue damage in a mouse model of mesenteric ischemia/reperfusion injury. PloS one. 7:e39934.

Leppert, D., J. Ford, G. Stabler, C. Grygar, C. Lienert, S. Huber, K.M. Miller, S.L. Hauser, and L. Kappos. 1998. Matrix metalloproteinase-9 (gelatinase B) is selectively elevated in CSF during relapses and stable phases of multiple sclerosis. Brain. 121:2327-2334.

Leppert, D., P. Hughes, S. Huber, B. Erne, C. Grygar, G. Said, K. Miller, A. Steck, A. Probst, and $P$. Fuhr. 1999. Matrix metalloproteinase upregulation in chronic inflammatory demyelinating polyneuropathy and nonsystemic vasculitic neuropathy. Neurology. 53:6262.

Letra, A., R.M. Silva, R.J. Rylands, E.M. Silveira, A.P. Souza, S.K. Wendell, G.P. Garlet, and A.R. Vieira. 2012. MMP3 and TIMP1 variants contribute to chronic periodontitis and may be implicated in disease progression. Journal of clinical periodontology. 39:707-716.

Li, G., Y. Yue, Y. Tian, M. Wang, H. Liang, P. Liao, W.T. Loo, M.N. Cheung, and L.W. Chow. 2012. Association of matrix metalloproteinase (MMP)-1, 3, 9, interleukin (IL)-2, 8 and cyclooxygenase (COX)-2 gene polymorphisms with chronic periodontitis in a Chinese population. Cytokine. 60:552-560.

Lijnen, H. 2001. Elements of the fibrinolytic system. Annals of the New York Academy of Sciences. 936:226-236.

Lim, H., and H.P. Kim. 2011. Matrix metalloproteinase-13 expression in IL-1 $\beta$-treated chondrocytes by activation of the p38 MAPK/c-Fos/AP-1 and JAK/STAT pathways. Archives of pharmacal research. 34:109-117.

Liu, X., L. Ye, Y. Bai, H. Mojidi, N.E. Simister, and X. Zhu. 2008. Activation of the JAK/STAT-1 signaling pathway by IFN-Y can down-regulate functional expression of the MHC class Irelated neonatal Fc receptor for IgG. The Journal of Immunology. 181:449-463.

Lodish, H., A. Berk, S.L. Zipursky, P. Matsudaira, D. Baltimore, and J. Darnell. 2000. The three roles of RNA in protein synthesis.

Lodish, H., and S.L. Zipursky. 2001. Molecular cell biology. Biochemistry and Molecular Biology Education. 29:126-133.

Lozano, R.M., M. Redondo-Horcajo, M.Á. Jiménez, L. Zilberberg, P. Cuevas, A. Bikfalvi, M. Rico, and G. Giménez-Gallego. 2001. Solution structure and interaction with basic and acidic fibroblast growth factor of a 3-kDa human platelet factor-4 fragment with antiangiogenic activity. Journal of Biological Chemistry. 276:35723-35734.

Lu, Q., and R.A. Malinauskas. 2011. Comparison of two platelet activation markers using flow cytometry after in vitro shear stress exposure of whole human blood. Artificial organs. 35:137-144.

Machlus, K.R., and J.E. Italiano. 2013. The incredible journey: From megakaryocyte development to platelet formation. The Journal of cell biology. 201:785-796. 
Makela, M., T. Salo, V.-J. Uitto, and H. Larjava. 1994. Matrix metalloproteinases (MMP-2 and MMP-9) of the oral cavity: cellular origin and relationship to periodontal status. Journal of dental research. 73:1397-1406.

Malemud, C.J. 2005. Matrix metalloproteinases (MMPs) in health and disease: an overview. Frontiers in bioscience: a journal and virtual library. 11:1696-1701.

Marcaccini, A.M., C.A. Meschiari, L.R. Zuardi, T.S. De Sousa, M. Taba, J.M. Teofilo, A.L. JacobFerreira, J.E. Tanus-Santos, A.B. Novaes, and R.F. Gerlach. 2010. Gingival crevicular fluid levels of MMP-8, MMP-9, TIMP-2, and MPO decrease after periodontal therapy. Journal of clinical periodontology. 37:180-190.

Marcus, A.J. 1978. The role of lipids in platelet function: with particular reference to the arachidonic acid pathway. Journal of lipid research. 19:793-826.

Mariani, G., C. Calastrini, F. Carinci, L. Bergamini, F. Calastrini, and G. Stabellini. 1996. Ultrastructural and histochemical features of the ground substance in cyclosporin Ainduced gingival overgrowth. Journal of periodontology. 67:21-27.

Martin, L.A. 2008. Negative Affect, Introversion, and Physiological Markers of Cardiovascular Disease. ProQuest.

McCawley, L.J., J. Wright, B.J. LaFleur, H.C. Crawford, and L.M. Matrisian. 2008. Keratinocyte expression of MMP3 enhances differentiation and prevents tumor establishment. The American journal of pathology. 173:1528-1539.

Meier, A., C. Kirschning, T. Nikolaus, H. Wagner, J. Heesemann, and F. Ebel. 2003. Toll-like receptor (TLR) 2 and TLR4 are essential for Aspergillus-induced activation of murine macrophages. Cellular microbiology. 5:561-570.

Mercado, F., R.I. Marshall, A.C. Klestov, and P.M. Bartold. 2000. Is there a relationship between rheumatoid arthritis and periodontal disease? Journal of clinical periodontology. 27:267272.

Michaud, D.S., Y. Liu, M. Meyer, E. Giovannucci, and K. Joshipura. 2008. Periodontal disease, tooth loss, and cancer risk in male health professionals: a prospective cohort study. The lancet oncology. 9:550-558.

Möhle, R., D. Green, M.A. Moore, R.L. Nachman, and S. Rafii. 1997. Constitutive production and thrombin-induced release of vascular endothelial growth factor by human megakaryocytes and platelets. Proceedings of the National Academy of Sciences. 94:663-668.

Mott, J.D., and Z. Werb. 2004. Regulation of matrix biology by matrix metalloproteinases. Current opinion in cell biology. 16:558-564.

Murakami, S., S. Takayama, K. Ikezawa, Y. Sltimabukuro, M. Kitamura, T. Nozaki, A. Terashima, T. Asano, and H. Okada. 1999. Regeneration of periodontal tissues by basic fibroblast growth factor. Journal of periodontal research. 34:425-430.

Murakami, S., S. Takayama, M. Kitamura, Y. Shimabukuro, K. Yanagi, K. Ikezawa, T. Saho, T. Nozaki, and H. Okada. 2003. Recombinant human basic fibroblast growth factor (bFGF) stimulates periodontal regeneration in class II furcation defects created in beagle dogs. Journal of periodontal research. 38:97-103.

Murphy, G. 2011. Tissue inhibitors of metalloproteinases. Genome biology. 12:1.

Nagase, H., R. Visse, and G. Murphy. 2006. Structure and function of matrix metalloproteinases and TIMPs. Cardiovascular research. 69:562-573.

Nagase, H., and J.F. Woessner, Jr. 1999. Matrix metalloproteinases. The Journal of biological chemistry. 274:21491-21494.

Nagata, Y., J. Yoshikawa, A. Hashimoto, M. Yamamoto, A.H. Payne, and K. Todokoro. 2003. Proplatelet formation of megakaryocytes is triggered by autocrine-synthesized estradiol. Genes \& development. 17:2864-2869. 
Nanci, A. 2008. Ten Cate's oral histology: development, structure, and function. St. Louis: Mosby Elsevier.

Natarajan, K., and B.C. Berk. 2006. Crosstalk coregulation mechanisms of G protein-coupled receptors and receptor tyrosine kinases. Methods Mol Biol. 332:51-77.

Nicu, E.A., U. Van der Velden, R. Nieuwland, V. Everts, and B.G. Loos. 2009. Elevated platelet and leukocyte response to oral bacteria in periodontitis. Journal of thrombosis and haemostasis : JTH. 7:162-170.

Odell, T., and C. Jackson. 1968. Polyploidy and maturation of rat megakaryocytes. Blood. 32:102-110.

Odell, T., C. Jackson, and T. Friday. 1970. Megakaryocytopoiesis in rats with special reference to polyploidy. Blood. 35:775-782.

Orkin, S.H., D.G. Nathan, D. Ginsburg, A.T. Look, D.E. Fisher, and S. Lux IV. 2008. Nathan and Oski's hematology of infancy and childhood. Elsevier Health Sciences.

Orozco, A., E. Gemmell, M. Bickel, and G. Seymour. 2007. Interleukin 18 and periodontal disease. Journal of dental research. 86:586-593.

Page, R.C., S. Offenbacher, H.E. Schroeder, G.J. Seymour, and K.S. Kornman. 1997. Advances in the pathogenesis of periodontitis: summary of developments, clinical implications and future directions. Periodontology 2000. 14:216-248.

Page, R.C., and H.E. Schroeder. 1976. Pathogenesis of inflammatory periodontal disease. A summary of current work. Laboratory investigation; a journal of technical methods and pathology. 34:235-249.

Page-McCaw, A., A.J. Ewald, and Z. Werb. 2007. Matrix metalloproteinases and the regulation of tissue remodelling. Nature reviews Molecular cell biology. 8:221-233.

Papapanagiotou, D., E.A. Nicu, S. Bizzarro, V.E. Gerdes, J.C. Meijers, R. Nieuwland, U. van der Velden, and B.G. Loos. 2009. Periodontitis is associated with platelet activation. Atherosclerosis. 202:605-611.

Parise, L.V. 1999. Integrin a Ilb $\beta 3$ signaling in platelet adhesion and aggregation. Current opinion in cell biology. 11:597-601.

Patel, S.R., J.H. Hartwig, and J.E. Italiano. 2005a. The biogenesis of platelets from megakaryocyte proplatelets. The Journal of clinical investigation. 115:3348-3354.

Patel, S.R., J.L. Richardson, H. Schulze, E. Kahle, N. Galjart, K. Drabek, R.A. Shivdasani, J.H. Hartwig, and J.E. Italiano. 2005b. Differential roles of microtubule assembly and sliding in proplatelet formation by megakaryocytes. Blood. 106:4076-4085.

PEASE, D.C. 1956. An electron microscopic study of red bone marrow. Blood. 11:501-526.

Perollet, C., Z.C. Han, C. Savona, J.P. Caen, and A. Bikfalvi. 1998. Platelet factor 4 modulates fibroblast growth factor 2 (FGF-2) activity and inhibits FGF-2 dimerization. Blood. 91:3289-3299.

Peters, J.-M., W.W. Franke, and J.A. Kleinschmidt. 1994. Distinct $19 \mathrm{~S}$ and $20 \mathrm{~S}$ subcomplexes of the $26 \mathrm{~S}$ proteasome and their distribution in the nucleus and the cytoplasm. Journal of Biological Chemistry. 269:7709-7718.

Ra, H.-J., and W.C. Parks. 2007. Control of matrix metalloproteinase catalytic activity. Matrix biology. 26:587-596.

Ramachandran, G. 2013. Biochemistry of collagen. Springer Science \& Business Media.

Ramos-DeSimone, N., E. Hahn-Dantona, J. Sipley, H. Nagase, D.L. French, and J.P. Quigley. 1999. Activation of matrix metalloproteinase-9 (MMP-9) via a converging plasmin/stromelysin-1 cascade enhances tumor cell invasion. Journal of Biological Chemistry. 274:13066-13076.

Ramseier, C.A., J.S. Kinney, A.E. Herr, T. Braun, J.V. Sugai, C.A. Shelburne, L.A. Rayburn, H.M. Tran, A.K. Singh, and W.V. Giannobile. 2009. Identification of pathogen and hostresponse markers correlated with periodontal disease. Journal of periodontology. 80:436-446. 
Rawlings, J.S., K.M. Rosler, and D.A. Harrison. 2004. The JAK/STAT signaling pathway. Journal of cell science. 117:1281-1283.

Reddy, N.R., D. Roopa, D.M. Babu, P.M. Kumar, C.M. Raju, and N.S. Kumar. 2012. Estimation of matrix metalloproteinase-3 levels in gingival crevicular fluid in periodontal disease, health and after scaling and root planing. Journal of Indian Society of Periodontology. 16:549.

Reuben, P.M., M.A. Brogley, Y. Sun, and H.S. Cheung. 2002. Molecular mechanism of the induction of metalloproteinases 1 and 3 in human fibroblasts by basic calcium phosphate crystals. Role of calcium-dependent protein kinase C alpha. The Journal of biological chemistry. 277:15190-15198.

Rinder, C., L. Student, J. Bonan, H. Rinder, and B. Smith. 1993. Aspirin does not inhibit adenosine diphosphate-induced platelet alpha-granule release. Blood. 82:505-512.

Roeb, E., K. Schleinkofer, T. Kernebeck, S. Pötsch, B. Jansen, I. Behrmann, S. Matern, and J. Grötzinger. 2002. The matrix metalloproteinase $9(\mathrm{mmp}-9)$ hemopexin domain is a novel gelatin binding domain and acts as an antagonist. Journal of Biological Chemistry. 277:50326-50332.

Rossa, C., M. Liu, P. Bronson, and K.L. Kirkwood. 2007. Transcriptional activation of MMP-13 by periodontal pathogenic LPS requires p38 MAP kinase. Journal of endotoxin research. 13:85-93.

Roux, P.P., and J. Blenis. 2004. ERK and p38 MAPK-activated protein kinases: a family of protein kinases with diverse biological functions. Microbiol Mol Biol Rev. 68:320-344.

Rucinski, B., S. Niewiarowski, P. James, D.A. Walz, and A.Z. Budzynski. 1979. Antiheparin proteins secreted by human platelets. Purification, characterization, and radioimmunoassay.[/sup 125/I tracer techniques]. Blood;(United States). 53.

Ruotsalainen, H., L. Sipilä, M. Vapola, R. Sormunen, A.M. Salo, L. Uitto, D.K. Mercer, S.P. Robins, M. Risteli, and A. Aszodi. 2006. Glycosylation catalyzed by lysyl hydroxylase 3 is essential for basement membranes. Journal of cell science. 119:625-635.

Sabroe, I., L.R. Prince, E.C. Jones, M.J. Horsburgh, S.J. Foster, S.N. Vogel, S.K. Dower, and M.K. Whyte. 2003. Selective roles for Toll-like receptor (TLR) 2 and TLR4 in the regulation of neutrophil activation and life span. The Journal of Immunology. 170:52685275.

Salmela, M.T., M.-L. Karjalainen-Lindsberg, P. Puolakkainen, and U. Saarialho-Kere. 2001. Upregulation and differential expression of matrilysin (MMP-7) and metalloelastase (MMP-12) and their inhibitors TIMP-1 and TIMP-3 in Barrett's oesophageal adenocarcinoma. British journal of cancer. 85:383.

Sang, Q.X.A. 1998. Complex role of matrix metalloproteinases in angiogenesis. Cell research. 8:171-177.

Sapna, G., S. Gokul, and K. Bagri-Manjrekar. 2014. Matrix metalloproteinases and periodontal diseases. Oral diseases. 20:538-550.

Scheuerer, B., M. Ernst, I. Dürrbaum-Landmann, J. Fleischer, E. Grage-Griebenow, E. Brandt, H.-D. Flad, and F. Petersen. 2000. The CXC-chemokine platelet factor 4 promotes monocyte survival and induces monocyte differentiation into macrophages. Blood. 95:1158-1166.

Semple, J.W., and J. Freedman. 2010. Platelets and innate immunity. Cell Mol Life Sci. 67:499511.

Semple, J.W., Y. Milev, D. Cosgrave, M. Mody, A. Hornstein, V. Blanchette, and J. Freedman. 1996. Differences in serum cytokine levels in acute and chronic autoimmune thrombocytopenic purpura: relationship to platelet phenotype and antiplatelet T-cell reactivity. Blood. 87:4245-4254.

Senior, R.M., G.L. Griffin, J.S. Huang, D.A. Walz, and T.F. Deuel. 1983. Chemotactic activity of platelet alpha granule proteins for fibroblasts. The Journal of cell biology. 96:382-385. 
Shapira, L., W.A. Soskolne, and T.E. Van Dyke. 1996. Prostaglandin E2 secretion, cell maturation, and CD14 expression by monocyte-derived macrophages from localized juvenile periodontitis patients. Journal of periodontology. 67:224-228.

Shimada, Y., S. Ichinose, A. Sadr, M. Burrow, and J. Tagami. 2009. Localization of matrix metalloproteinases (MMPs-2, 8, 9 and 20) in normal and carious dentine. Australian dental journal. 54:347-354.

Shubayev, V.I., and R.R. Myers. 2000. Upregulation and interaction of TNFa and gelatinases A and $B$ in painful peripheral nerve injury. Brain research. 855:83-89.

Smith, M.F., A. Mitchell, G. Li, S. Ding, A.M. Fitzmaurice, K. Ryan, S. Crowe, and J.B. Goldberg. 2003. Toll-like receptor (TLR) 2 and TLR5, but not TLR4, are required for Helicobacter pylori-induced NF-kB activation and chemokine expression by epithelial cells. Journal of Biological Chemistry. 278:32552-32560.

Smith, P.C., V.C. Muñoz, L. Collados, and A.D. Oyarzún. 2004. In situ detection of matrix metalloproteinase-9 (MMP-9) in gingival epithelium in human periodontal disease. Journal of periodontal research. 39:87-92.

Sorsa, T., L. Tjäderhane, and T. Salo. 2004. Matrix metalloproteinases (MMPs) in oral diseases. Oral diseases. 10:311-318.

Spinale, F.G., M.L. Coker, L.J. Heung, B.R. Bond, H.R. Gunasinghe, T. Etoh, A.T. Goldberg, J.L. Zellner, and A.J. Crumbley. 2000. A matrix metalloproteinase induction/activation system exists in the human left ventricular myocardium and is upregulated in heart failure. Circulation. 102:1944-1949.

Sricholpech, M., I. Perdivara, H. Nagaoka, M. Yokoyama, K.B. Tomer, and M. Yamauchi. 2011. Lysyl hydroxylase 3 glucosylates galactosylhydroxylysine residues in type I collagen in osteoblast culture. Journal of Biological Chemistry. 286:8846-8856.

Srivastava, K., D.J. Field, A. Aggrey, M. Yamakuchi, and C.N. Morrell. 2010. Platelet factor 4 regulation of monocyte KLF4 in experimental cerebral malaria. PloS one. 5:e10413.

Sternlicht, M.D., A. Lochter, C.J. Sympson, B. Huey, J.-P. Rougier, J.W. Gray, D. Pinkel, M.J. Bissell, and Z. Werb. 1999. The stromal proteinase MMP3/stromelysin-1 promotes mammary carcinogenesis. Cell. 98:137-146.

Strieter, R.M., T.J. Standiford, G.B. Huffnagle, L.M. Colletti, N.W. Lukacs, and S.L. Kunkel. 1996. " The good, the bad, and the ugly." The role of chemokines in models of human disease. The Journal of Immunology. 156:3583-3586.

Stuckey, J.A., R.S. Charles, and B.F. Edwards. 1992. A model of the platelet factor 4 complex with heparin. Proteins: Structure, Function, and Bioinformatics. 14:277-287.

Takayama, S., S. Murakami, Y. Shimabukuro, M. Kitamura, and H. Okada. 2001. Periodontal regeneration by FGF-2 (bFGF) in primate models. Journal of Dental Research. 80:20752079.

Takayama, S.-i., J. Yoshida, H. Hirano, H. Okada, and S. Murakami. 2002. Effects of basic fibroblast growth factor on human gingival epithelial cells. Journal of periodontology. 73:1467-1473.

Tallant, C., A. Marrero, and F.X. Gomis-Rüth. 2010. Matrix metalloproteinases: fold and function of their catalytic domains. Biochimica et Biophysica Acta (BBA)-Molecular Cell Research. 1803:20-28.

Tarzemany, R., G. Jiang, H. Larjava, and L. Hakkinen. 2015. Expression and function of connexin 43 in human gingival wound healing and fibroblasts. PloS one. 10:e0115524.

Terpenning, M.S., G.W. Taylor, D.E. Lopatin, C.K. Kerr, B.L. Dominguez, and W.J. Loesche. 2001. Aspiration pneumonia: dental and oral risk factors in an older veteran population. Journal of the American Geriatrics Society. 49:557-563.

Tewari, D.S., Y. Qian, M. Tewari, J. Pieringer, R.D. Thornton, R. Taub, and E.O. Mochan. 1994. Mechanistic features associated with induction of metalloproteinases in human gingival fibroblasts by interleukin-1. Archives of oral biology. 39:657-664. 
Tipton, D.A., and M.K. Dabbous. 1995. Effects of nicotine on proliferation and extracellular matrix production of human gingival fibroblasts in vitro. Journal of periodontology. 66:1056-1064.

Tonetti, M.S. 2009. Periodontitis and risk for atherosclerosis: an update on intervention trials. Journal of Clinical Periodontology. 36:15-19.

Tortorella, M.D., E.C. Arner, R. Hills, A. Easton, J. Korte-Sarfaty, K. Fok, A.J. Wittwer, R.-Q. Liu, and A.-M. Malfait. 2004. $\alpha 2-$ Macroglobulin is a novel substrate for ADAMTS-4 and ADAMTS-5 and represents an endogenous inhibitor of these enzymes. Journal of Biological Chemistry. 279:17554-17561.

Tüter, G., B. Kurtis, and M. Serdar. 2002. Effects of phase I periodontal treatment on gingival crevicular fluid levels of matrix metalloproteinase- 1 and tissue inhibitor of metalloproteinase-1. Journal of periodontology. 73:487-493.

Uehara, A., and H. Takada. 2007. Functional TLRs and NODs in human gingival fibroblasts. Journal of dental research. 86:249-254.

Uitto, V.-J., K. Airola, M. Vaalamo, N. Johansson, E.E. Putnins, J.D. Firth, J. Salonen, C. LópezOtín, U. Saarialho-Kere, and V. Kähäri. 1998. Collagenase-3 (matrix metalloproteinase13) expression is induced in oral mucosal epithelium during chronic inflammation. The American journal of pathology. 152:1489.

Van Raemdonck, K., M. Gouwy, S.A. Lepers, J. Van Damme, and S. Struyf. 2014. CXCL4L1 and CXCL4 signaling in human lymphatic and microvascular endothelial cells and activated lymphocytes: involvement of mitogen-activated protein (MAP) kinases, Src and p70S6 kinase. Angiogenesis. 17:631-640.

Vandenbroucke, R.E., E. Dejonckheere, F. Van Hauwermeiren, S. Lodens, R. De Rycke, E. Van Wonterghem, A. Staes, K. Gevaert, C. López-Otin, and C. Libert. 2013. Matrix metalloproteinase 13 modulates intestinal epithelial barrier integrity in inflammatory diseases by activating TNF. EMBO molecular medicine. 5:1000-1016.

Vandercappellen, J., J. Van Damme, and S. Struyf. 2011. The role of the CXC chemokines platelet factor-4 (CXCL4/PF-4) and its variant (CXCL4L1/PF-4var) in inflammation, angiogenesis and cancer. Cytokine Growth Factor Rev. 22:1-18.

Vincent, D., J. Lefort, F. Chatelet, M.F. Bureau, J. Dry, and B.B. Vargaftig. 1993. Intratracheal E. coli lipopolysaccharide induces platelet-dependent bronchial hyperreactivity. J Appl Physiol (1985). 74:1027-1038.

Vincenti, M.P. 2001. The matrix metalloproteinase (MMP) and tissue inhibitor of metalloproteinase (TIMP) genes. Matrix Metalloproteinase Protocols:121-148.

Vincenti, M.P., and C.E. Brinckerhoff. 2002. Transcriptional regulation of collagenase (MMP-1, MMP-13) genes in arthritis: integration of complex signaling pathways for the recruitment of gene-specific transcription factors. Arthritis research. 4:157-164.

Visse, R., and H. Nagase. 2003. Matrix metalloproteinases and tissue inhibitors of metalloproteinases structure, function, and biochemistry. Circulation research. 92:827839.

Wallon, U.M., and C.M. Overall. 1997. The Hemopexin-like Domain (C Domain) of Human Gelatinase A (Matrix Metalloproteinase-2) Requires Ca2+ for Fibronectin and Heparin Binding BINDING PROPERTIES OF RECOMBINANT GELATINASE AC DOMAIN TO EXTRACELLULAR MATRIX AND BASEMENT MEMBRANE COMPONENTS. Journal of Biological Chemistry. 272:7473-7481.

Wang, P.-L., and K. Ohura. 2002. Porphyromonas gingivalis lipopolysaccharide signaling in gingival fibroblasts-CD14 and Toll-like receptors. Critical Reviews in Oral Biology \& Medicine. 13:132-142.

Wang, S., X. Wei, J. Zhou, J. Zhang, K. Li, Q. Chen, R. Terek, B.C. Fleming, M.B. Goldring, and M.G. Ehrlich. 2014. Identification of $\alpha 2-$ Macroglobulin as a Master Inhibitor of Cartilage- 
Degrading Factors That Attenuates the Progression of Posttraumatic Osteoarthritis. Arthritis \& rheumatology. 66:1843-1853.

Watson, J.B., S.B. Getzler, and D.F. Mosher. 1994. Platelet factor 4 modulates the mitogenic activity of basic fibroblast growth factor. Journal of Clinical Investigation. 94:261.

Wen, G., C. Zhang, Q. Chen, L.A. Luong, A. Mustafa, S. Ye, and Q. Xiao. 2015. A novel role of matrix metalloproteinase-8 in macrophage differentiation and polarization. Journal of Biological Chemistry. 290:19158-19172.

West, A.P., I.E. Brodsky, C. Rahner, D.K. Woo, H. Erdjument-Bromage, P. Tempst, M.C. Walsh, Y. Choi, G.S. Shadel, and S. Ghosh. 2011. TLR signalling augments macrophage bactericidal activity through mitochondrial ROS. Nature. 472:476-480.

Weyrich, A.S., S. Lindemann, N.D. Tolley, L.W. Kraiss, D.A. Dixon, T.M. Mahoney, S.P. Prescott, T.M. Mclntyre, and G.A. Zimmerman. 2004. Change in protein phenotype without a nucleus: translational control in platelets. In Seminars in thrombosis and hemostasis. Vol. 30. Copyright@ 2004 by Thieme Medical Publishers, Inc., 333 Seventh Avenue, New York, NY 10001, USA. 491-498.

Weyrich, A.S., and G.A. Zimmerman. 2003. Evaluating the relevance of the platelet transcriptome. Blood. 102:1550-1551.

White, J., and G. Escolar. 1991. The blood platelet open canalicular system: a two-way street. European journal of cell biology. 56:233-242.

White, J.G., and C. Clawson. 1980. The surface-connected canalicular system of blood platelets--a fenestrated membrane system. The American journal of pathology. 101:353.

Woulfe, D., J. Yang, N. Prevost, P.J. O'Brien, and L. Brass. 2002. Signal transduction during the initiation, extension, and perpetuation of platelet plug formation. Platelets:197-213.

Xiong, X., P. Buekens, W. Fraser, J. Beck, and S. Offenbacher. 2006. Periodontal disease and adverse pregnancy outcomes: a systematic review. BJOG: An International Journal of Obstetrics \& Gynaecology. 113:135-143.

Yamauchi, M., and M. Sricholpech. 2012. Lysine post-translational modifications of collagen. Essays in biochemistry. 52:113-133.

Yu, K.-m., Y. Inoue, M. Umeda, H. Terasaki, Z.-y. Chen, and T. Iwai. 2011. The peridontal anaerobe Porphyromonas gingivalis induced platelet activation and increased aggregation in whole blood by rat model. Thromb Res. 127:418-425.

Zaldivar, M.M., K. Pauels, P. von Hundelshausen, M.L. Berres, P. Schmitz, J. Bornemann, M.A. Kowalska, N. Gassler, K.L. Streetz, and R. Weiskirchen. 2010. CXC chemokine ligand 4 $(\mathrm{Cxcl} 4)$ is a platelet-derived mediator of experimental liver fibrosis. Hepatology. 51:13451353.

Zhang, X., L. Chen, D.P. Bancroft, C. Lai, and T.E. Maione. 1994. Crystal structure of recombinant human platelet factor 4. Biochemistry. 33:8361-8366.

Zhou, J., J. Zhang, and J. Chao. 2012. Porphyromonas gingivalis promotes monocyte migration by activating MMP-9. Journal of periodontal research. 47:236-242.

Zucker, M.B., and I.R. Katz. 1991. Platelet factor 4: production, structure, and physiologic and immunologic action. Proc Soc Exp Biol Med. 198:693-702.

Zucker, S., M. Drews, C. Conner, H.D. Foda, Y.A. DeClerck, K.E. Langley, W.F. Bahou, A.J. Docherty, and J. Cao. 1998. Tissue inhibitor of metalloproteinase-2 (TIMP-2) binds to the catalytic domain of the cell surface receptor, membrane type 1-matrix metalloproteinase 1 (MT1-MMP). Journal of Biological Chemistry. 273:1216-1222. 